\title{
Islet Endothelium: Role in Type 1 Diabetes and in Coxsackievirus Infections
}

\author{
Enrica Favaro, Ilaria Miceli, Elisa Camussi and Maria M. Zanone \\ Department of Internal Medicine, University of Turin, \\ Italy
}

\section{Introduction}

The heterogeneity of microvascular endothelial cells derived from different organs, suggests that these cells have specialised functions at different anatomical sites. The microvasculature is, in fact, a key interface between blood and tissues and participates in numerous pathophysiological processes. Pancreatic islet microcirculation exhibits distinctive features, in an interdependent physical and functional relationship with $\beta$ cells, from organogenesis to adult life. The islet microendothelium behaves as an active "gatekeeper" in the control of leukocyte recruitment into the islets during autoimmune insulitis in type 1 diabetes.

Furthermore, microvascular endothelial cells, forming the key lining between the vascular space and organ parenchyma, have been shown to influence organ and tissue specific susceptibility to viral infection, and to modulate the pathological expression of virusinduced diseases, which potentially includes type 1 diabetes. Endothelial cells expressing appropriate receptors would fail to act as effective barrier to infections, allowing viral particles to pass through, and replicate in, the vascular endothelium. Human Enteroviruses (EV), especially those of the Coxsackievirus B (CVB) group, are associated with a wide variety of clinical syndromes and have long been considered possible culprits of inflammatory conditions and immune-mediated pathological processes, such as chronic dilated cardiomyopathy, chronic myositis and type 1 diabetes mellitus (Rose et al., 1993; Luppi et al., 1998; Hyöty \& Taylor, 2002). Several mechanisms, including molecular mimicry, bystander activation of autoreactive $\mathrm{T}$ cells, superantigenic activity of viral proteins, not mutually exclusive, have been proposed to explain the relationship between EV infections and induction of autoimmune diseases (Varela-Calvino \& Peakman, 2003; Horwitz et al., 1998; Wucherpfennig, 2001). Evidences of a link between viral infections and initiation or acceleration of pancreatic islet autoimmunity have been under investigation for almost 30 years, and EVs, especially those of the Coxsackievirus B (CVB) group, are historically the prime suspects as important aetiological determinants in type 1 diabetes (Hyöty \& Taylor, 2002; Varela-Calvino \& Peakman, 2003). Endothelial cells derived from different organs show distinct susceptibility to CVB infections, and the behaviour against a viral challenge of endothelial cells in large vessels and microvessels may differ (Friedman et al. 1981; Huber et al., 1990; Conaldi et al. 1997; Zanone et al., 2003; Saijets et al., 2003). 


\section{Pancreatic islet microvasculature: Structure and specialised functions}

It is widely accepted that remarkable heterogeneity of endothelial phenotype and function exists amongst different vascular beds (Kubota et al., 1988; Charo etal., 1984; Swerlick et al., 1991; Swerlick et al., 1992; Fujimoto \& Singer, 1988; Lidington et al., 1999), in particular between cells derived from large versus small vessels, supporting the notion that tissue-specific vascular beds have specialised functions. These diversities include morphology, growth requirement in vitro (Kubota et al., 1988; Charo et al., 1984; Swerlick et al., 1991; Swerlick et al., 1992; Fujimoto \& Singer, 1988; Lidington et al., 1999, Folkman et al., 1979) prostaglandin secretory profile (Charo etal., 1984), immunologic phenotype (Swerlick et al., 1992) and amounts and regulation of cell adhesion molecules (Swerlick et al., 1992; Fujimoto \& Singer, 1988; Petzelbauer et al., 1993; Swerlick A.R., et al., 1992; Lee et al., 1992). At a functional level, differential and sequential expression of adhesion molecules mediates trafficking of leukocytes to specific lymphoid and nonlymphoid tissues.

Endothelium heterogeneity is the result of microenvironmental signals, in particular those induced by the family of vascular endothelial growth factor (VEGF) proteins (D'Amore \& $\mathrm{Ng}$, 2002). VEGF is a major stimulator of neovascularisation by inducing proliferation and migration of endothelial cells and tube formation. Pancreatic islets are one of the most vascularised organs, having a blood perfusion of about $10 \%$ of that of the whole pancreas, despite representing only $1 \%$ of the gland; this reflects high exchange demand with the endocrine cells and high metabolic supply (Figure 1). Deletion studies indicate that VEGF-A is responsible for this dense islet vascularisation, being more expressed in the endocrine than the exocrine pancreas (Lammert et al., 2003). Endothelial cells migrate to the source of VEGF-A, the neighboring $\beta$ cells, proliferate and form blood vessels, organised in a network of sinusoidal capillaries reminiscent of those present in the renal glomerulus, with a five times higher density and ten times more fenestrations than in the exocrine tissue.

Islets receive blood from 1 to 3 arterioles and drain into collecting venules forming a network covering the islet surface, and an insulo-acinar portal system connects the islet capillaries with capillaries of the exocrine pancreas. The pattern of blood flow within the islet is still a matter of debate, with the $\beta$ cell-rich islet core possibly perfused before the non$\beta$ cells in the periphery of the islet (Brunicardi et al., 1996).

Specific markers of islet microvasculature have been identified. These include the $\alpha-1$ proteinase inhibitor (Api, $\alpha-1$ antitrypsin), a major proteinase inhibitor with immunoregulatory properties, and nephrin ( Favaro et al., 2005), a highly specific barrier protein, known to be located in the renal glomerular ultrathin filter membrane "slit diaphragm" (Ruotsalainen et al., 1999; Tryggvason \& Wartiovaara, 2001) (Figure 2). The nephrin expressed in islet microendothelial cells has functional characteristics that are highly reminiscent of the same protein expressed by podocytes in the renal glomeruli, in that in both cell types treatment with TNF- $\alpha$ acts on the cell cytoskeleton to induce a marked redistribution of nephrin expression. Nephrin is a cell adhesion transmembrane protein of the immunoglobulin superfamily, which has a pivotal role in the regulation of renal glomerular selective permeability (Henderson \& Moss, 1985; Bonner-Weir, 1993; Konstantinova \& Lammert, 2004; Bonner-Weir \& Orci, 1982). Islet endothelial expression of this protein is consistent with the ultrastructural features of these cells in the islets, which form a microvasculature that is characterized by a glomerulus-like network of fenestrated capillaries. 


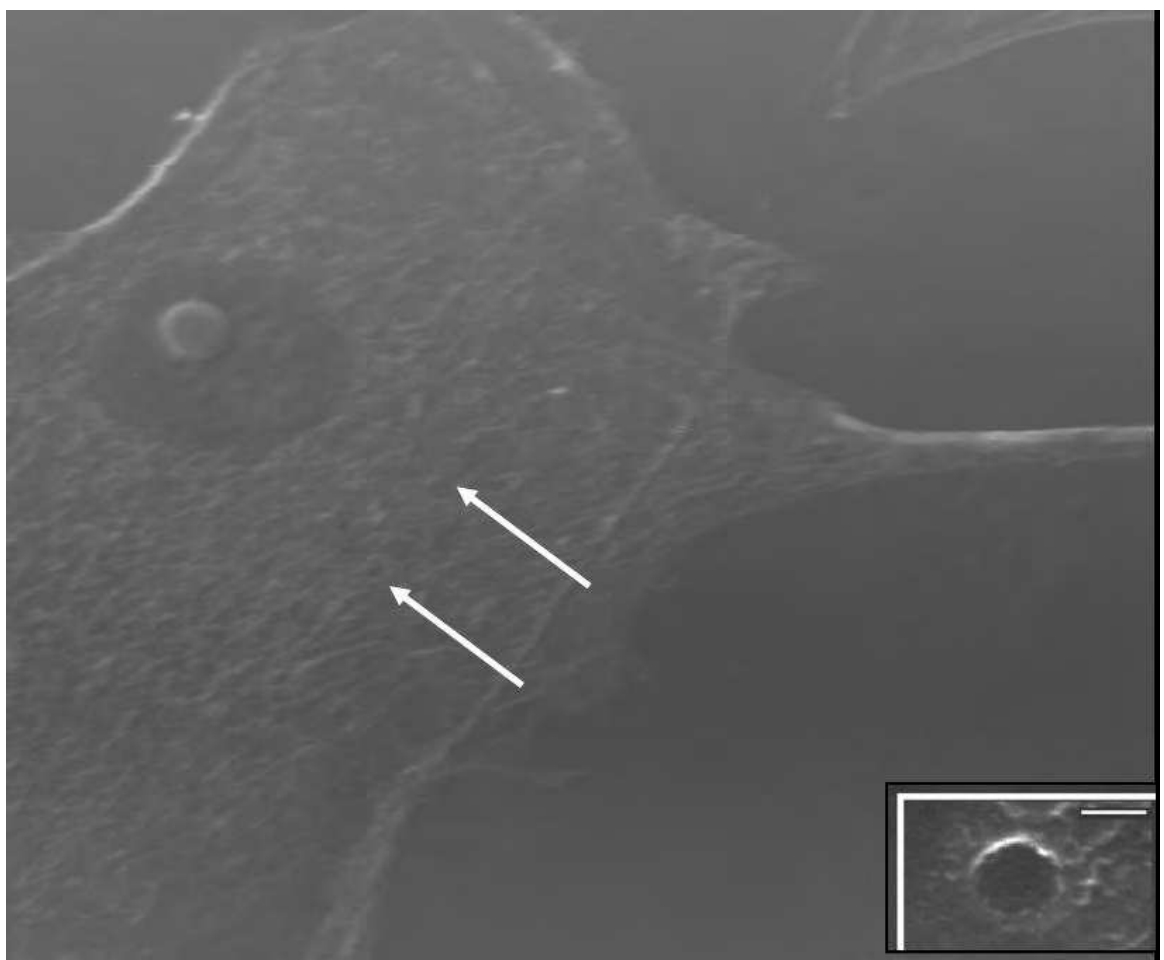

Fig. 1. Cultured islet endothelial cells.

Representative micrograph of scanning electron microscopy of primary islet MECs. The arrows show typical cellular fenestrations (original magnification 1500X). Inset: representative magnification of a cellular fenestra (original magnification 15,000X). Bar: $0.1 \mu \mathrm{m}$.

Nephrin appears to be more than just a structural component, as it is an adhesion and signalling molecule that can activate mitogen-activated protein kinase cascades, modulating a variety of cellular programs, including proliferation, differentiation and apoptosis (Karin et al., 1997; Flickinger \& Olson, 1999). It has been shown that nephrin, once phosphorylated associates with PI3K and itself stimulates the Akt-dependent signaling pathway (Huber et al., 2003) that plays a pivotal role in preventing apoptosis in a variety of settings (Datta et al., 1999). In particular, Akt activation is crucial for the ability of factors such as insulin, IGF-I and VEGF to inhibit apoptosis in cultured endothelium (Jung et al., 2000). Recent data highlight the Akt role also in insulin-mediated glucose transport and pancreatic $\beta$ cell mass and function (Bernal-Mizrachi et al., 2004; Elghazi et al., 2006).

Islet endothelium is crucially involved in fine-tuning blood glucose sensing and regulation (Lammert et al., 2003). Besides providing oxygen and nutrients to the endocrine cells, islet endothelium is in fact involved in the trans-endothelial rapid passage of secreted insulin into the circulation. In perfusion experiments with horseradish peroxidase it has been demonstrated that the endothelial fenestrae are sites through which proteins quickly permeate (Takahashi et al., 2002). Thus the islet fenestrae allow the fastest way for insulin to enter the circulation. Studies in mice with pancreatic VEGF-A deletion, showed that these 
mice not only displayed loss of endothelial fenestrations and thicker endothelial cell body but also defective blood glucose levels on glucose tolerance test, pointing to a possible defect in the release of insulin (Lammert et al., 2003). A more recent study indicated that mice with $\beta$ cell reduced VEGF-A expression show impaired glucose-stimulated insulin secretion, related to vascular alterations of the islets (Brissova et al., 2006).

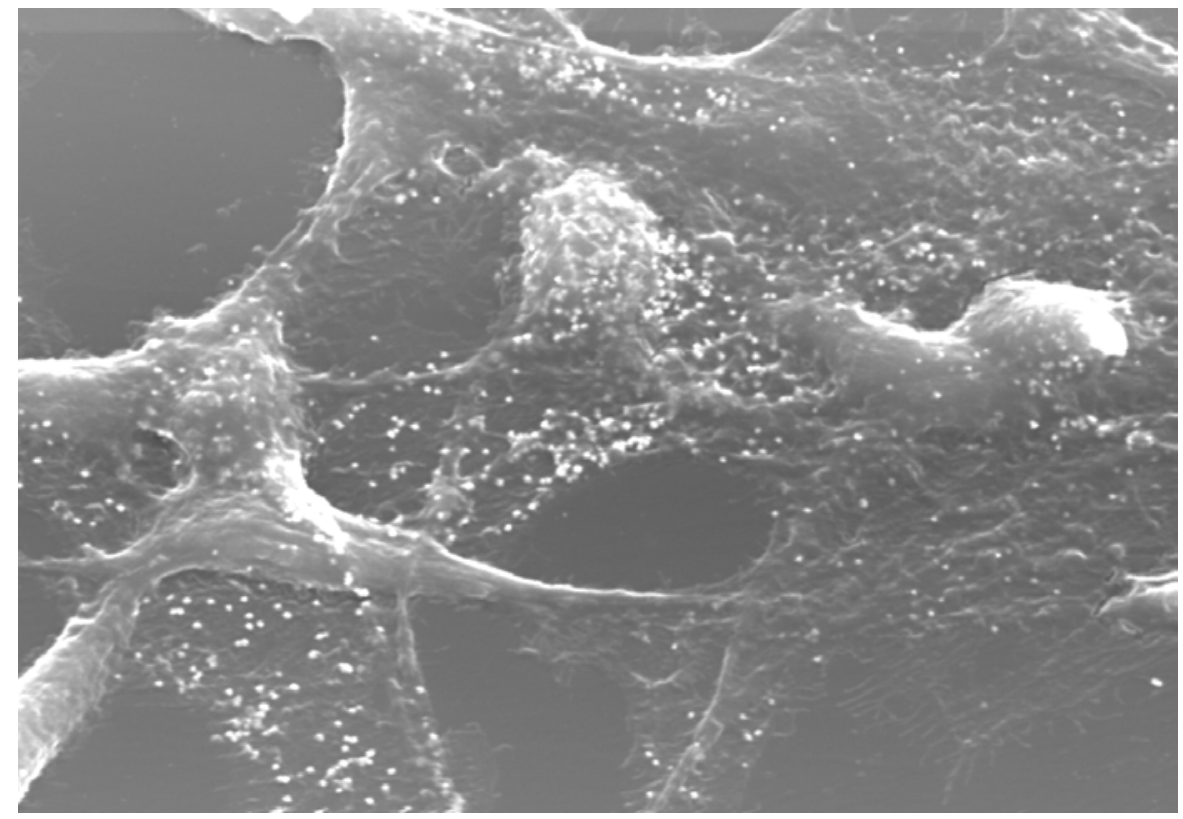

Fig. 2. Nephrin is expressed by islet endothelial cells.

Representative immunogold labelling micrograph of islet MECs stained with anti-nephrin Abs. By immunogold staining, nephrin appears distributed on the surface of islet MECs, without accumulation at cell-to-cell junctions (original magnification 1000X).

The microvasculature participates in sensing the environment of the islets and generates signals to affect adult islet endocrine function, being accepted that post-natal $\beta$ cell mass is dynamic and can increase in function and mass to compensate for added demand (BonnerWeir \& Sharma, 2006). In an in vitro system, purified islet endothelial cells have been shown to stimulate $\beta$ cell proliferation, through secretion of hepatocyte growth factor (HGF) (Suschek et al., 1994). VEGF-A and insulin are the islet-derived factor that induce HGF secretion. In vivo experiments, using pancreas of pregnant rats in which a high physiological proliferation of $\beta$ cell occurs, showed prominent expression of HGF, coinciding with the peak of $\beta$ cell proliferation.

Islet endothelium exhibits a unique phenotype also in the activities of the constitutive and cytokine-inducible endothelial nitric oxide (NO) synthases, forming the vasoactive mediator NO, since these enzymes are specifically regulated by the glucose level (Kolb \& KolbBachofen, 1992). This indicates an organ-specific control of NO production, whose role in islet cytotoxicity is well established (Kroncke et al., 1993; Steiner et al., 1997; Southern et al., 1990; Schmidt et al., 1992). The role of NO in the physiology of insulin release instead 
remains controversial (Welsh \& Sandler, 1992; Corbett et al., 1993; Henningsson et al., 2002; von Andrian \& Mackay CR, 2000; Ostermann et al., 2002).

Immunohistochemical studies have shown that the expression of Platelet-activating factor (PAF) receptor (PAF-r) within the islet, is restricted to endothelial cells, providing potential target for therapeutic intervention (Biancone et al., 2006). PAF, is a phospholipid with diverse physiological effects that mediates a host of biochemical activities, including angiogenesis and inflammation. Islet endothelial cells have also been shown to rapidly produce PAF under stimulation with trombin, and PAF accelerated angiogenesis (Mattsson et al., 2006). These data suggest that intra-islet production of PAF, induced by inflammatory mediators, may contribute to the neovascularisation of transplanted islets.

Lastly, islet endothelial cells express genes encoding for a number of other factors involved in angiogenesis, including potent pro-angiogenic factors, such as VEGF, and angiostatic factors, such as endostatin and pigment epithelial-derived factor (Lammert et al., 2001).

\subsection{Endothelial signalling during development and interplay between endothelial and $\beta$ cells}

Elegant experiments on early pancreatic development demonstrated that blood vessel endothelium in the dorsal aorta provides inductive signals for the differentiation of the primitive endoderm into islet cells (Lammert et al., 2001; Yoshitomi \& Zaret, 2004). In vivo embryonic manipulation of frog embryos to block the formation of the dorsal aorta endothelium, leads to failure of pancreatic gene and insulin expression. To assay blood vessel-pancreas interactions later in development, VEGF-A was overexpressed in transgenic mice using the pancreatic promoter, $P d x 1$; this leads to hypervascularisation of the pancreas and hyperplasia of the pancreatic islets (threefold increase in islet area), at the expense of acinar cell types. Further, coculture experiments with endoderm and dorsal aortic endothelium from early mouse embryos, result in pancreatic gene $P d x 1$ induction and insulin expression, indicating that endothelial signals are sufficient for the pancreatic organogenesis program. A successive study on pancreatic organogenesis, has shown that aortal endothelial cells induce in the dorsal pancreatic endoderm the crucial pancreatic transcription factor Ptfla, that has been shown to be necessary for the development of endocrine and duct cell lineages.

A two sep-model for islet development has been proposed (Konstantinova \& Lammert, 2004): the first step involves signals from the endothelium to the pancreatic epithelium, the second involves signals in the opposite direction, with islets expressing VEGF-A at later stages of their development to attract capillaries. As for the molecular basis for such signals, recent studies indicate that $\beta$ cells, by using VEGF-A attract endothelial cells, which form capillaries with a vascular basement membrane next to the $\beta$ cells. In turn, laminins, amongst other vascular basement membrane proteins, regulate insulin gene expression and $\beta$ cell proliferation; these effects require $\beta_{1}$ integrin on $\beta$ cells (Nikolova et al., 2006).

Studies on $\beta$ cell proliferation in humans are limited, but there is evidence that this process occurs at relatively high levels in the first 2 years of life, declining thereafter, with the possibility, at least in animals, of re-induction under conditions of insulin-resistance, such as pregnancy or obesity (Meier et al., 2008; Cnop et al., 2010). This suggests that $\beta$ cell may retain an intrinsic capacity to replicate, and an increase of the islet vasculature has been observed in association with conditions of expanded islet mass (Mizuno et al., 1999; Like 
1970; Predescu et al., 1998). Islet endothelium-derived hepatocyte growth factor (HGF) is one of the factors potentially involved in the stimulation of $\beta$ cell proliferation (Suschek et al., 1994).

Also collagen IV and other basement membrane proteins, laminins, could potentiate insulin secretion, promote insulin gene expression and proliferation in $\beta$ cells, via interaction with integrin $\alpha_{1} \beta_{1}$ on $\beta$ cell (Treutelaar et al., 2003; Kroncke et al., 1991).

These studies confirm the existence of an endothelial-endocrine axis within adult pancreatic islets.

\section{Islet endothelium and type 1 diabetes}

Islet endothelium forms the barrier across which autoreactive $\mathrm{T}$ cells transmigrate during the development of islet inflammation in autoimmune diabetes. Transendothelial migration and recruitment of autoreactive $T$ cells into the pancreatic islets is a critical event during the development of chronic insulitis in type 1 diabetes. Transmigration is a complex, multistep process involving first selectins and their counter ligands that induce rolling of cells along the luminal surface of endothelial cells, followed by firm adhesion between cells and endothelium, and diapedesis (von Andrian \& Mackay, 2000).

Several human and murine studies indicate that during autoimmune insulitis, the endothelial cells surrounding the inflamed islets adopt an activated phenotype, upregulate a variety of adhesion molecules, and are likely to be involved in regulating mononuclear cell accumulation (transmigration and homing) in the islets (Hanafusa et al., 1990; Hanninen et al., 1992; Hanninen et al., 1993; Itoh et al., 1993; Somoza et al.,1994). Activation of the islet endothelium may either initiate or enhance subsequent leukocyte infiltration of the islets. The islet endothelium is able to hyperexpress adhesion molecules, to secrete numerous cytochines and chemokines, and to hyperexpress class I and class II HLA molecules (Itoh et al., 1993; Somoza et al.,1994; Alejandro et al., 1982). Endothelial cells participate also in presentation of cognate antigens to $\mathrm{T}$ cells, which has potent effects on their migration in vitro and in vivo (Epperson \& Pober, 1994; Marelli-Berg et al., 1999; Marelli-Berg et al., 2004; Pober et al., 2001) .

In particular, in humans, immunohistological studies of islets obtained near to the time of type 1 diabetes diagnosis, show abundant adhesion molecule expression on vessel and immune cells. In particular, bioptic studies showed that infiltrating mononuclear cells consisted of $\mathrm{CD}^{+} \mathrm{T}$, predominant $\mathrm{CD}^{+} \mathrm{T}$ and $\mathrm{B}$ lymphocytes and macrophages, accompanied by increased expression class I and class II HLA antigens in endothelial cells (Itoh et al.,1993; Greening et al., 2003; Lozanoska-Ochser \& Peakman, 2005). Pancreatic islet endothelial MHC class I hyperexpression has been observed also in NOD mice and the biobreeding rat model of autoimmune diabetes (Kay et al., 1991; Ono et al., 1988), and represents a mechanism through which tissue-specific migration of $\mathrm{T}$ cells is refined and promoted.

In support to this, human islet endothelial cells have been shown in vitro to be capable of internalizing, processing and presenting to autoreactive CD4 T cell clones, disease-relevant epitopes of the islet autoantigen GAD65 (Greening et al., 2003; Di Lorenzo et al., 2007). This resulted in markedly enhanced transmigration.

Islet endothelial cells have also been shown to possess the necessary repertoire of the costimulatory molecules for adequate $\mathrm{T}$ cell activation. In vitro studies on the molecular 
interactions between generated human islet endothelial cells and autoreactive $\mathrm{T}$ cells, indicate that islet endothelial cells constitutively express the CD86 (B7-2) and ICOS-L, but not CD80 (B7-1) and CD40 costimulatory molecules. Such co-stimulatory molecules are capable of functionally co-stimulating $\mathrm{CD} 4^{+} \mathrm{T}$ cell activation, and to help activated memory $\left(\mathrm{CD} 45 \mathrm{R}^{+}\right) \mathrm{CD} 4 \mathrm{~T}$ cells to migrate across the endothelial barrier (Lozanoska et al., 2008). These studies provide strong indication that islet endothelium actively participates in the recruitment of recently activated lymph node migrant autoreactive $\mathrm{T}$ cells. Blockade of the costimulation may represent a mode of in vivo action of intervention therapies that interfere with costimulation, such as CTLA-4 Ig (abatacept). Furthermore, analysis of the immunophenotype of endothelial cells, focusing on endothelial MHC class I molecule expression, in a range of different tissues and mouse strain, including the NOD mice, shows that MHC levels have a profound effect on activation, adhesion and transmigration of pathogenic, islet autoreactive CD8 T cells (Lozanoska-Ochser \& Peakman, 2009). These finding have a direct relevance to the pathogenesis of autoimmune diabetes in the MOD mouse, and are in concert with those with Savinov et al. (Savinov et al., 2001) who demonstrated that homing of a diabetogenic insulin-specific CD8+ T cell clone was severely impaired when clone cells were infused in IFN- $\gamma$ knock-out mice, despite normal adhesion to the microvasculature. More recently, the same authors showed that islet-specific homing of the same diabetogenic clone depends in part upon recognition of the cognate $\mathrm{MHC} /$ peptide complexes presented by pancreatic islet endothelial cells, which are presumed to acquire insulin from adjacent $\beta$ cells (Savinov et al., 2003).

Based on these observations, it is proposed the model in which, during islet inflammation due to as-yet non-defined environmental insult (possibly a viral infection), cytokines and other inflammatory mediators, such as IFN- $\gamma$, are released and elicit activation of vascular endothelium. Endothelial activation leads to increased adhesion and extravasation of leukocytes. Further, insulin, to high level of which endothelial cells are chronically exposed, and islet antigens released by damaged $\beta$ cells, may be taken up by activated endothelial cells, processed and presented to autoreactive T cells.

Furthermore, sustained and intermitted hyperglycemia has been shown to affect endothelial cellular survival and proliferation, including islet microendothelium (Favaro et al., 2008). Several metabolic mechanisms are involved, including oxidative stress, increased intracellular $\mathrm{Ca}^{++}$, mitochondrial dysfunction, changes in intracellular fatty-acid metabolism, impaired tyrosine phosphorylation and activation of PI3K/Akt and ERK1/2 pathways and reduced intracellular cAMP and its target, the cAMP-dependent PKA pathways (Datta et al., 1999; Favaro et al., 2010). These multifunctional pathways transmit signals that result in prevention of apoptosis or induction of cell cycle progression, depending on the cell type and can cross-regulate one another (Stork \& Schmitt, 2002). Akt signaling cascade has also a role in insulin-mediated glucose transport and pancreatic $\beta$-cell mass and function (Bernal-Mizrachi et al., 2004; Elghazi et al., 2006 ). Pro-survival Bcl-2 protein, which stabilizes the mitochondrial membrane and prevents the release of cytocrome c from the mitochondria and the activation of caspases (Choy et al., 2001), is also found to be down-regulated by high glucose in human islet microendothelial cells. In contrast, the pro-apoptotic member Bax, which antagonizes Bcl-2, is up-regulated (Favaro et al., 2010). It is noteworthy that over-expression of Bcl-2 in endothelial cells has been described to decrease $\mathrm{T}$ cell cytotoxicity, suggesting that this protein may also protect endothelial cells from apoptosis resulting from an immunological insult (Zheng et al., 2000). 
Due to the established interdependent physical and functional relationship between islet endothelium and $\beta$ cells, from pancreatic organogenesis to adult life (Zanone et al., 2008), and the notion that post-natal $\beta$-cell mass is dynamic and can increase in function and mass for added demand by replication or neogenesis, possibly through endothelial inductive signals (Nikolova et al., 2006; Johansson et al., 2006; Bonner-Weir \& Sharma, 2002; Dor et al., 2004), these high glucose-induced changes in islet endothelium carry relevant consequences on $\beta$ cells. In fact, production of the vasoactive mediator NO (Meier, 2008; Favaro et al., 2008) to upregulate CD40L expression in human islet microendetelial cells in vitro (Favaro et al., 2010). Functional CD40L is expressed on vascular endothelium (Mach et al., 1997) and contributes to B cell activation, isotype switching, costimulation in T cell mediated immunity, activation of extravasating monocytes (Yang \& Wilson, 1996; Wagner et al., 2004), with an impact in atherosclerosis and in chronic inflammatory and autoimmune diseases. Blockers of the CD40L have been strikingly effective in animal models of autoimmune diseases, such as systemic lupus erythematosus and type 1 diabetes (Homann et al., 2002). Therefore, high glucoseinduced overexpression of CD40L on islet endothelial cells might accelerate the targeting and loss of the remaining $\beta$-cell capacity during ongoing autoimmune insulitis.

In fact, production of the vasoactive mediator NO by islet endothelium (Meier, 2008; Favaro et al., 2008) is increased in hyperglycaemic conditions and has an established direct cytotoxicity on islets and potentially impairs insulin release (Corbett JA et al., 1993). Islet microendothelial cells also are source of the proinflammatory cytokine IL- $1 \beta$ under hyperglycaemic conditions, independently of any viral or immune-mediated process. IL- $1 \beta$ impairs insulin release in human islet, induces Fas expression enabling Fas-mediated apoptosis and it is implicated as a mediator of glucotoxicity (Maedler K, et al. 2002). The high glucose condition is also reported to upregulate CD40L expression in human islet microendothelial cells in vitro (Favaro E et al., 2010).

\section{Enteroviruses and type 1 diabetes}

Viral infection has been long implicated in the development of type 1 diabetes and evidences of a link between viral infections and initiation or acceleration of pancreatic islet autoimmunity have been under investigation for more than 30 years. Rubella virus (Karvonen et al., 1993), mumps virus (Hyoty et al., 1988), cytomegalovirus (Ward et a., 1979), rotavirus (Honeyman et al., 2000) and enteroviruses (EV) (Lonnrot et al., 2000; Stene et al., 2010) have all been suggested as environmental factors contributing to type 1 diabetes. EV, especially those of the Coxsackievirus B (CVB) group (Hyöty et al., 1988; Varela-Calvino \& Peakman , 2003; Green et al., 2004), are historically the prime suspects as important aetiological determinants and seroepidemiological, histopathological, animal studies, and in vitro experiments have provided the strongest overall evidence for these viruses. The EV genus of the Picornaviridae family is a large group of human pathogens traditionally divided into polioviruses, coxsackieviruses, echoviruses and the new EV, and each group contains a range of serotypes (King et al., 2000; Roivainen, 2006). Human EV are the most common cause of viral infection in humans, are associated with a wide variety of clinical syndromes and have long been considered possible culprits of inflammatory conditions and immune-mediated pathological processes, such as chronic myocarditis, dilated cardiomyopathy and chronic myositis (Tam, 2006; Luppi et al., 2000). In the cardiac context, injury is caused by a direct cytopathic effect of the virus, an immune response to viral infection or autoimmunity triggered by the viral infection (Huber, 2006). 
Several mechanisms, including molecular mimicry, bystander activation of autoreactive $\mathrm{T}$ cells, superantigenic activity of viral proteins, viral infection and persistence, not mutually exclusive, have been proposed to explain the relationship between EV infections and induction of autoimmune diseases (extensively reviewed in Varela-Calvino \& Peakman, 2003; Ercolini \& Miller, 2009).

As for a role in type 1 diabetes, results have been somewhat conflicting and not conclusive (von Herrath, 2009; Tauriainen et al., 2010). Autoantibodies to islet autoantigens are detected years prior to diagnosis of type 1 diabetes and prospective studies evaluating whether EV could predict islet autoimmunity have yielded conflicting results, with positive associations in the Finnish studies (Lönnrot et al., 2000; Salminen et al., 2003; Sadeharju et al., 2003), and no association in other reports (Graves et al., 2003; Füchtenbusch et al., 2001). Discrepancies could be related to the fact that in most studies the determination of EV infection was carried out indirectly through the determination of IgM and IgG anti-EV antibodies, while studies using multiple approaches to identify EV infection (serology, RT-PCR, faeces analysis) appear more likely to report an association with type 1 diabetes or islet autoimmunity. A higher frequency of EV RNA has been consistently shown in the serum of patients with diabetes compared to healthy control subjects, demonstrating a recent or a persistent infection (Lönnrot, M., Salminen, K., et al., 2000; Lönnrot, M., Korpela, K., et al., 2000), and in some of the cases the detection of EV RNA preceded the synthesis of islet cell autoantibodies. In most studies viruses of the CVB group, usually CVB3 and CVB4 were identified (Clements et al., 1995; Andréoletti et al., 1997; Chehadeh et al., 2000), in agreement with serological studies.

As for $\mathrm{T}$ cell responses to EV, studies are inconclusive. However, it has been shown that CD4 T cells from newly diagnosed patients up-regulate CD69 early activation marker after exposure to CVB4-infected lysates (Varela-Calvino et al., 2001) and produce more IFN- $\gamma$ a proinflammatory cytokine generated by effector memory CD4 $\mathrm{T}$ cells, but show less $\mathrm{T}$ cell proliferation (Varela-Calvino \& Peakman, 2003). Proliferation is dependent upon IL-2 secretion associated with central memory T cells. This implies that anti-CVB4 effector cells are mobilized from the central memory pool, which may be depleted. Response to CVB4 antigens at diabetes diagnosis appears thus to be active, indicating recent or prolonged exposure.

Results from animal models indicate that viral infections per se usually cannot initiate the autoimmune disease process leading to diabetes, but may accelerate an already ongoing disease process. Studies in various NOD mice strains show that EV infections may accelerate the progression to diabetes only if they occur after autoreactive $\mathrm{T}$ cells have been accumulated in the islets (Hiltunen et al.,1997; Lönnrot et al., 1998; Lönnrot et al., 2000; Otonkoski et al., 2000). CVB infection appears to accelerate the development of the disease via bystander activation of autoreactive $T$ cells, due to inflammation of the pancreas, tissue damage, release of sequestered autoantigens in concert with production of proinflammatory cytokines, all leading to activation of autoreactive T cells, but apparently only when a certain threshold of these autoreactive $\mathrm{T}$ cells have already accumulated in the pancreas. Timing of a CVB infection, rather than its simple presence or absence, may thus have etiological implications for the development of type 1 diabetes.

A recent report evaluating whether such a general model of disease progression rather than initiation by EV applies to human type 1 diabetes (Stene et al., 2010), suggests that progression from islet autoimmunity to type 1 diabetes in high-risk individuals may increase after an EV infection characterised by the presence of viral RNA in blood. Indeed, most EV are avid triggers of production of pro-inflammatory cytokines by human 
leukocytes (Vreugdenhil et al., 2000), notably type I interferons, and it is noteworthy that increased levels of IFN- $\gamma$ have been detected in the blood of newly diagnosed patients (Chehadeh et al., 2000), and EV RNA was detected in half of the IFN- $\alpha$ positive patients. These data are consistent with a recent EV infection.

\subsection{Enteroviruses and pancreatic islets}

Major determinants of the different clinicopathological manifestations of EV infections, ranging from silent infections to autoimmune diseases, are represented by the viral variants, the nature of the infection, acute, chronic or re-infection, and the distinct tissue tropism of the viral strain, modulated by the local expression of appropriate cellular receptors and coreceptors. The first step in viral infection is the attachment of the virus to its receptor, a cell surface molecule which viruses have adapted to use for their entry into the cells. These include the Coxsackie-Adenovirus receptor (CAR), integrin VLA-2, $\alpha_{v} \beta_{3}, \alpha_{v} \beta_{5}$, ICAM- 1 and decayaccelerating factor (DAF) (Bergelson et al., 1997; Noutsias et al., 2001; Shafren, 1998). In cultured cells, CVB have been found to interact with at least three receptors. CAR is a 46kD adhesion molecule and all tested clinical and laboratory isolates bind to this receptor (Bergelson, 2002; Kallewaard et al., 2009). A large subset of CVB isolates also binds to DAF, a complement regulatory protein (Coyne \& Bergelson, 2006) which appears to act as a receptor for cell attachment (Shafren et al., 1995), and some CVB3 isolates have been shown to use a third receptor, heparan sulfate, to infect CAR-deficient cells in vitro (Zautner et al., 2003).

These receptor molecules do not simply bind viruses, but may activate a series of events influencing the organ-specific outcome of disease (Ito et al., 2000; Selinka et al., 2004 ). CAR expression, for instance, is positively related to the extent of inflammation in the cardiac myosin-induced myocarditis model (Ito et al., 2000), and knockout of MyD88, an adaptor involved in toll-like receptor signaling, causes reduced cardiac expression of CAR and proinflammatory cytokines (Fuse et al., 2005) or TGF- $\beta$ reduced CAR levels inhibit CVB3 infection of cardiac myocytes (Shi et al., 2010). CAR appears as the major receptor mediating CVB infection also in the pancreas in vitro and in vivo, since tissue-specific CAR gene deletion generated a 1000-fold reduction in virus titres within the pancreas during infection, and a significant reduction in virus-induced pancreatic tissue damage and inflammation (Kallewaard et al., 2009).

While acute infection in the pancreas has been clearly detected among the cells of the exocrine tissue, $\beta$ cell infection by EV has been extensively studied and the issue of whether microvariants of EV can directly infect, replicate and persist in, and cause damage of $\beta$ cells remains controversial (Flodstrom et al., 2002). More than three decade ago Yoon et al. showed that CVB4 is capable of replicating in cultured human islets (Yoon et al., 1978). Other works suggested that the CVB group has variants that can replicate in islet cells (Harting et al., 1983; Chatterjee et al.,1988), and by growing viruses on islets of Langerhans it is possible to isolate strains that can induce insulitis experimentally in animals and replicate in islet cells in vivo. Prototype CVB3, CVB4 and CVB5 as wells as CVA9 can replicate in vitro in purified insulin-producing $\beta$ cells, and infection may result in functional impairment or cytolytic death of the $\beta$ cells, but it may also have no apparent adverse effect (Roivainen et al., 2000; Roivainen et al., 2002). It appears that the consequences of the virus replication on $\beta$ cell survival and function are not entirely dependent on the serotype but on a as-yet unidentified characteristics of the virus strain. For instance, between the diabetogenic strain E2 of CVB4 and the prototype CVB4, a 111 amino acid difference has been identified, and 
amino acids or nucleotides potentially most critical for the pathogenesis of type 1 diabetes have to be identified amongst the microvariants of relevant virus strains.

Another work (Chehadeh et al., 2000) indicates that the CVB group is capable to replicate at a low level in human islet cells in vitro, persisting without cytolytic effect. This replication is associated with chronic synthesis of IFN- $\alpha$ by the islet cells. Neutralization of the IFN- $\alpha$ leads to a rise in viral replication and rapid islet destruction.

Type I interferons induce an anti-viral state in infected cells, providing an early defense against viral infections (Stark et al., 1998), and it appears that $\beta$ cells may depend on interferons to lower their permissiveness to CVB4 infection, thus regulating the susceptibility to virus-induced diabetes (Flodstrom et a., 2002; Flodstrom et al., 2003). In this model, NOD mice that expressed the suppressor of cytokine signalling 1 (SOCS-1) in $\beta$ cells developed diabetes, due to the replication of the virus in the $\beta$ cells. A critical link between the target $\beta$ cell antiviral responses and susceptibility to disease is thus established.

Furthermore, due to its immunoregulatory properties, IFN- $\alpha$ represents a link between the innate and the adaptive immunity: a pathological event may commence with activation of the innate immune system in order to avoid cytolytic destruction, followed by $\mathrm{T}$ cell activation and expansion, including autoreactive $\mathrm{T}$ cells. Viral expansion of non-specific $\mathrm{T}$ cell responses has been shown to be mimicked by injection of IFN- $\alpha$ (Tough \& Sprent, 1996), or IFN- $\alpha$ expression by pancreatic $\beta$ cells (Stewart et al., 1993; Chakrabarti et al., 1996). In humans, IFN- $\alpha$ has been detected in $\beta$ cells (Foulis et al., 1987; Huang et al., 1995) and in blood of type 1 diabetic patients (Chehadeh et al., 2000).

A very recent report, indicates that rare genetic variations occurring in the gene IFIH1 and affecting the expression and structure of its protein product IFIH, lower the risk of developing type 1 diabetes (Nejentsev et al., 2009). IFIH1 triggers the secretion of interferons. Another study showed that IFIH1 expression in peripheral blood cells is associated with type 1 diabetes (Liu et al., 2009). These data allows to speculate that, on viral infection, interferon-response genes are activated in insulin-producing cells, leading to increased levels of interferons. Interferons inhibit viral replication, but also enhance the expression of surface MHC-I molecules. Cytotoxic CD8 T cells recognize infected $\beta$ cells, through the MHC-I molecules, damaging and eventually killing them. Thus, viral infection can contribute to the development of type 1 diabetes.

As for in vivo studies in humans, the isolation of an EV has been documented only few times. Historically, CVB4 was successfully cultured from the pancreas of a diabetic child at disease onset and it induced diabetes in susceptible animals, more than 30 years ago (Yoon et al., 1979). The diabetogenic E2 strain was likewise obtained by plaque purification of the human isolate Edwards of CVB4, that was isolated from a child with widespread CVB4 infection, presenting with acute myocarditis and pancreatitis (Chatterjee et al., 1988).

In contrast with the apparent success in the detection of EV mRNA from blood, no EV genome could be detected when pancreas from cases of type 1 diabetes were analysed post-mortem during the first year after diagnosis (Foulis et al., 1997). However, in the same study EV genome could be detected in the pancreas of children who died of acute myocarditis in which the heart was EV positive. These discrepancies may be explained with the argument that there is a critical window for virus detection in the pancreas, and this is only potentially achieved when there is an acute presentation of viral illness, as in the case of myocarditis. By in situ hybridisation studies on post-mortem pancreatic tissues of several type 1 diabetic patients, EV RNA positive cells were for the first time detected, and exclusively in islets (Ylipaasto et al., 2004). 
In recent years, other studies have eventually indicated the presence of EV in pancreatic tissue in a sizable proportion of patients dying soon after diabetes onset (Tauriainen et al., 2009; Dotta et al., 2007; Richardson et al., 2009; Ylipaasto et al., 2004). A $\beta$ cell infectious CVB4 was isolated in the pancreas of three patients at disease onset, by immunohistochemical, electron microscopy, genome nucleotide sequencing, cell culture and immunological studies (Dotta et al., 2007). Infection was specific to $\beta$ cells, which showed islet inflammation mediated mainly by natural killer cells, reduced insulin secretion. The virus was also able to infect $\beta$ cells from human islets of non diabetic donors.

A strain of echovirus 3 was isolated from an individual currently with appearance of islet cell and IA-2 autoantibodies (Williams at al., 2006). Richardson et al (Richardson et al., 2009) identified EV VP1 capsid protein in islets of 44 out of 72 recent-onset type 1 diabetic patients, and the staining was restricted to $\beta$ cells. A recent report suggests that the virus is present in the intestinal mucosa of diabetic patients (Oikarinen et al., 2008).

These detection reports strengthen the case for a viral role in the pathogenesis of type 1 diabetes.

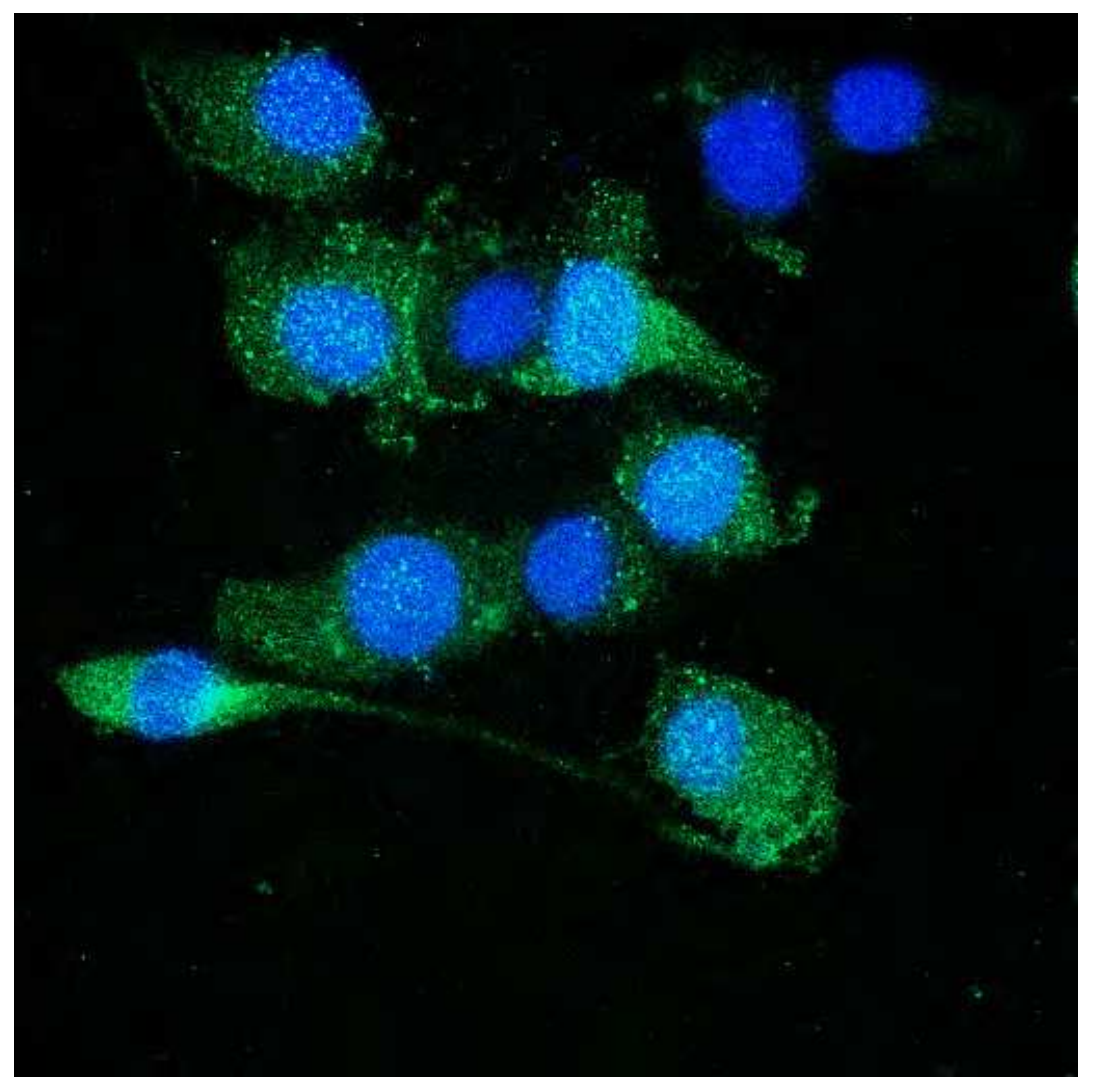

Fig. 3. Representative confocal immunofluorescence micrographs of islet MECs, stained with polyclonal anti-HCAR Ab, showing a diffuse expression in a fine punctate pattern in islet MECs (original magnification 630X, nuclei stained in blue with DAPI). 


\subsection{Coxsackievirus infection and endothelial cells}

The host factors modulating viral infections include not only the host immune response, but also types and characteristics of cells that become infected in different tissues. Parenchymal cells of an organ are rarely in direct contact with the circulatory system, and viruses in the circulation must either circumvent or infect vascular endothelial cells to reach secondary organs. Vascular endothelial cells act in fact as important interface between the vascular space and the organ parenchyma, and, as previously stated, endothelial cells in different organs exhibit diverse structural and functional characteristics that can influence biological and pathological functions. Amongst these, vascular endothelial cells have an established role as mediators of tissue tropism and access for virus, influencing organ and tissue specific susceptibility to viral infection. Therefore, they can modulate the pathological expression of virus-induced diseases (Friedman et al., 1981; Huber et al., 1990; Conaldi et al., 1997; Zanone et al., 2003). For instance, in murine studies on CVB infectivity of different organs, CVB3 isolates from the heart showed greater infectivity and replication in heart endothelial cells than endothelial cells derived from liver or lung (Huber et al., 1990), thus confirming the essential role of host factors in developing specific diseases.

In line with this scenario, it is essential that, to gain access to secondary organs, viruses pass through the vascular endothelium by transcytosis or infection, or via infected circulating cells migrating into the target tissues. Endothelial cells derived from different organs show distinct susceptibility to CVB infections, and the behaviour against a viral challenge of endothelial cells in large vessels and microvessels may differ (Friedman et al., 1981; Huber et al., 1990; Conaldi et al., 1997; Zanone et al., 2003; Saijets et al., 2003). Endothelial cells expressing appropriate receptors would fail to act as effective barrier to infections, allowing viral particles to pass through, and replicate in, the vascular endothelium.

Human umbilical vein-derived endothelial cells have been shown to be persistently infected by different CVB strains (Flodstrom et al., 2000; Huber et al., 1990; Conaldi et al., 1997).

However, physiological and pathological events take place mainly at the level of the microvasculature. Using a dermal microvascular endothelial cell line, we have provided evidence that small vessel endothelial cells can harbour a persistent CVB viral infection (Zanone et al., 2003). All 3 CVB tested productively infected microvascular endothelial cells for up to 3 months without obvious cytolysis. A small proportion of the cells, approximately $10 \%$, appeared to be involved in viral replication during chronic infection, suggesting that persistence is probably established through a mechanism of carrier-state culture, as proposed to explain CVB persistence in other cell types (Flodstrom et al., 2002; Greening et al., 2003). In addition, the infection increased production of proinflammatory cytokines IL-6 and IL-8, indicating endothelial cell activation by virus, and induced quantitative modification of adhesion molecule expression (ICAM-1, VCAM-1). These upregulation may influence the pattern of migration and extravasation of leucocytes in inflammation and immunity. These data add weight to the view that common CV infections are able to trigger complex pathophysiological processes, rather than simple cell lysis, as is becoming increasingly evident in clinical and experimental settings. These viruses can in fact persist for a considerable time in infected patients and cause chronic pathology or trigger immunopathological damage to infected and uninfected tissues (Muir et al., 1989; Stone, 1994). Furthermore, chronic infection of endothelial cells in vivo could provide better viral access to tissues underlying the endothelial layer and subsequent parenchymal cell infection. 
The mechanisms of CVB persistence is not clear. It is possible that the infected cells undergo cytolysis and release virions to infect more cells, thus maintaining a chronic infection of the culture without massive cell destruction. Alternatively, it could be hypothesized that the cells can cure themselves of viruses, e.g. by limiting production of cell host products required for viral replication, or by production of anti-viral mediators. Stability of the cell membrane could also be another important factor in the ability of infected cells to survive infection, without lysis. In previous studies, the distinct susceptibility of different cell types to long-term infection has been related to the production of interferons (Conaldi et al., 1997; Heim et al., 1992).

It has also been suggested that the persistent infection of cultured HUVEC may be due to down-regulation of viral receptors in infected cells. However, a study indicates that the expression of the specific CVB receptor, CAR, in these cells was not quantitatively altered by infection with CVB but rather by culture confluence (Huber et al., 1990).

Human islet endothelial cells have been more recently shown to express the specific human Coxsackievirus and Adenovirus receptor (HCAR) (Figure 3) and CVB co-receptors, such as DAF, integrins and ICAM-1, that have differentiated functions on virus attachment and entry into target cells (Zanone et al., 2007). Islet endothelial cells can harbour a persistent, low level infection by CVB, assessed as detection of VP1 capsid protein and release of infectious particles. The infection has no obvious effects on cell morphology or viability and can provide better viral access to the underlying islet tissue. Under experimental conditions to avoid massive cytolysis and possibly to mimic silent in vivo infection, as EV infections can cause little or no clinical symptoms, only a proportion of cells appeared to be involved in viral replication, suggesting a mechanism of carrier-state culture (Conaldi et al., 1997; Zanone et al., 2003).

Notably, the infection of islet enodothelial cells upregulates the expression of DAF, HCAR and integrin $\alpha_{\mathrm{v}} \beta_{3}$, in contrast to the behaviour of other macro- and microvascular endothelial cells lines, i.e. HUVEC, HMEC-1 and human aortic ECs. In fact, it has been shown that CVB infection downregulates DAF on HUVEC and HMEC-1 (Zanone et al., 2003), leaves HCAR expression unchanged on HUVEC (Carson et al., 1999), and downregulates HCAR expression and upregulates DAF expression on human aortic endothelial cells (Zanone et al., 2007).

This differential behaviour underlines the widely accepted heterogeneity of phenotype and function amongst endothelial cells derived from different vascular beds (Swerlick et al., 1992; Lidington et al., 1999), and may be relevant for the pathological sequelae of the infection. Despite detailed knowledge of the molecular structure and virus interaction of HCAR, its biological and possible pathogenic relevance are uncertain. HCAR belongs to the immunoglobulin superfamily and appears to have signalling functions (Bergelson et al., 1997; Noutsias et al., 2001; Fechner et al., 2003). Remarkably, CAR has been shown to be upregulated on affected cardiomyocytes in a rat model of experimental autoimmune myocarditis (Ito et al., 2000) and in human idiopatic dilated cardiomyopathy (Noutsias et al., 2001), for which EVs are the most frequently implicated pathogens (Feldman, 2000). CAR expression could therefore represent a key determinant of cardiac susceptibility to viral infections and have a pathogenic relevance in chronic cardiomyopathies. It has also been suggested that cell-to-cell contact modulates CAR-to-CAR interaction-based signals (Carson et al., 1999; Fechner et al., 2003). 
The CVB infection upregulates in islet endothelial cells the expression of adhesion molecules and increases the production of proinflammatory cytokines and chemokines such as IL-1 $\beta$, IL-6, IL-8 as well as IFN- $\alpha$, once again pointing to endothelial cell activation (Zanone et al., 2007), in line with studies that suggest that a low-grade inflammation may cause profound impairments of endothelial function (Hingonari et al., 2000; Charakida et al., 2005).

In time course analyses, infected cells transiently upregulated expression of two major adhesion molecules, which may have in vivo functional consequences, enhancing cellular recruitment and leading to persistent tissue inflammation.

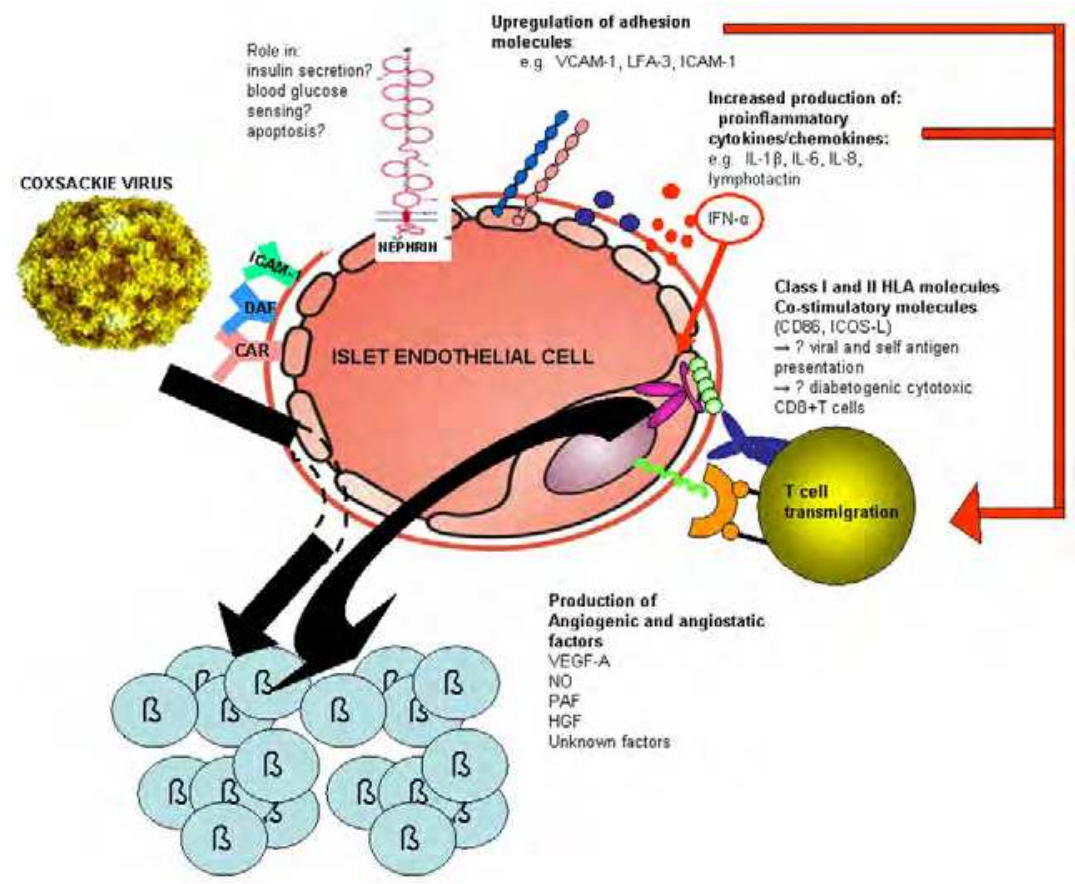

Fig. 4. Schematic representation of the relationship between Coxsackievirus infection, islet endothelial cells and $\beta$ cells.

The highly fenestrated endothelial cells exhibit expression of classical endothelial markers, adhesion and co-stimulatory molecules, with the potential of being involved in autoreactive $\mathrm{T}$ cell adhesion, activation and transmigration in type 1 diabetes. They express specific markers, such as nephrin, whose functions at this site remain to be unravelled. Human islet endothelial cells express receptors and coreceptors for Coxsackievirus (such as HCAR, DAF, integrin and ICAM-1). These cells are potential target of an acute or persistent CVB infection, that activates the endothelium, upregulates expression of adhesion molecules, increases the production of proinflammatory cytokines and chemokines, and provides better viral access to tissues underlying the endothelial layer. Moreover, the increased production of IFN-a may enhance the expression of surface class I and II HLA molecules involved in viral and self antigen presentation, with selective recruitment and expansion of cytotoxic CD8+ T cells, which recognize infected endothelial and $\beta$ cells, eventually damaging and killing them. 
Infection also increased the production of pro-inflammatory cytokines, IL-1 $\beta$, IL-6 and IL-8, further contributing to viral pathogenetic sequelae and to an indirect amplification of virus specific and non-specific responses. In this scenario, an exacerbated local inflammatory response secondary to viral infection represents an attempt to restrict virus replication, but it could promote chemoattraction and homing of circulating viral or, in susceptible individuals, islet antigen-specific T cells, in a bystander activation model (Horwitz et al., 1998). Cytokines may also be directly toxic to $\beta$ cells, leading to release of sequestered antigens, presentation by professional dendritic cells, and activation of autoantigen-specific T cells. Endothelial cells themselves may serve as antigen-presenting cells (Greening et al., 2003; Savinov et al., 2003).

The infection was also accompanied by increased production of IFN- $\alpha$, that has a role in initiation and maintenance of chronic CVB infection, as shown for other infected cell lines including islet $\beta$ cells, and in line with the extensive studies documenting abnormal localization of IFN- $\alpha$ in the pancreas of type 1 diabetic patients (Chehadeh et al., 2000, Huber et al., 1990, Conaldi et al., 1997; Heim et al., 1992). As stated above, IFN- $\alpha$ may be responsible for a viral expansion of non-specific $T$ cell responses, including autoreactive $T$ cells.

Again, in dilated cardiomyopathy inflammatory endothelial activation is present, and endothelial CAM expression correlates with the intramyocardial counterreceptor-bearing lymphocyte infiltrates (Noutsias et al., 1999; Seko et al., 1993). In this model, it is likely that endothelial cells are infected before cardiotropic viruses invade the myocardium (Klingel et al., 1992).

An increased production of lymphotactin RNA by the infected cells is also reported. Lymphotactin is a chemokine with the ability to chemoattract highly specifically CD4 ${ }^{+}$and CD8+ T cells and NK cells (Kennedy et al., 1995; Hedrick et al., 1997), with possible anti-viral and anti-tumor effects. An inappropriate $\mathrm{T}$ cell infiltration, drawn by lymphotactin, is present in other inflammatory conditions (Middel et al., 2001; Blaschke et al., 2003), and lymphotactin exposed on infected islet endothelial cells could, therefore, play a role in islet infiltration by $\mathrm{T}$ cells.

The endothelium infection may thus contribute to selective recruitment and expansion of subsets of leukocytes during inflammatory immune responses in type 1 diabetes. These findings add to a body of work that highlights the possible role of human EVs as environmental triggers that are capable of influencing the incidence of type 1 diabetes, the susceptibility of which to environmental influences is well established.

\section{Conclusion}

There is a body of work that highlights the possible role of human EVs as environmental triggers that are capable of influencing the incidence of type 1 diabetes, the susceptibility of which to environmental influences is well established (Hyöty \& Taylor, 2002; VarelaCalvino \& Peakman, 2003). Vascular endothelial cells have a major role in viral tropism and disease pathogenesis. Islet endothelium appears to be endowed of distinctive structural and functional features, and is acquiring a role in type 1 and type 2 diabetes (Figure 4). An interaction between islet endothelium and an EV, CVB in particular, infection might trigger a series of pro-inflammatory events that could be important in islet inflammation and possibly influence the development of autoimmune diabetes, through the initiation or acceleration of islet autoimmunity in susceptible individuals. 


\section{References}

Alejandro, R., Shienvold, F.L., Hajek, S.V., Ryan, U., Miller, J., \& Mintz, D.H. (1982). Immunocytochemical localization of HLA-DR in human islets of Langerhans. Diabetes, Vol. 31 Suppl 4, pp 17-22, ISSN 1939-327X

Andréoletti, L., Hober, D., Hober-Vandenberghe, C., Belaich, S., Vantyghem, M.C., Lefebvre, J., \& Wattré, P. (1997). Detection of coxsackie B virus RNA sequences in whole blood samples from adult patients at the onset of type I diabetes mellitus. J Med Virol, Vol. 52, pp 121-127, ISSN 1096-9071

Bergelson, J. M.,Cunningham, J. A., Droguett, G., Kurt-Jones, E. A., Krithivas, A., Hong, J. S., Horwitz, M. S., Crowell, R. L., \& Finberg, R. W. (1997). Isolation of a common receptor for Coxsackie B viruses and Adenoviruses 2 and 5. Science, Vol. 275, pp 1320-1323, ISSN 1095-9203

Bernal-Mizrachi, E., Fatrai, S., Johnson, J.D., Ohsugi, M., Otani, K., Han, Z., Polonsky, K.S., \& Permutt, M.A. (2004). Defective insulin secretion and increased susceptibility to experimental diabetes are induced by reduced Akt activity in pancreatic islet beta cells. J Clin Invest, Vol. 114, pp 928-936, ISSN 1558-8238

Bergelson, J.M. (2002). Receptors for coxsackieviruses and echoviruses. In: Molecular Biology of Picornaviruses. Washington, DC: ASM Press, Semler BL, Wimmer E, editors. pp 107-113, ISBN 1-55581-210-4

Biancone, L., Cantaluppi, V., Romanazzi, G.M., Russo, S., Figliolini, F., Beltramo, S., Scalabrino, E., Deregibus, M.C., Romagnoli, R., Franchello, A., Salizzoni, M., Perin, P.C., Ricordi, C., Segoloni, G.P., \& Camussi, G. (2006). Platelet-activating factor synthesis and response on pancreatic islet endothelial cells: relevance for islet transplantation. Transplantation, Vol. 81, pp 511-518, ISSN 1534-0608

Blaschke, S., Middel, P., Dorner, B. G., Blaschke, V., Hummel, K. M., Kroczek, R. A., Reich, K. P., Benoehr, M., Koziolek, M., \& Muller, G. A. (2003). Expression of activationinduced, $\mathrm{T}$ cell-derived, and chemokine-related cytokine/lymphotactin and its functional role in rheumatoid arthritis. Arthritis Rheum., Vol. 48, pp 1858-1872, ISSN 1529-0131

Bonner-Weir, S., \& Orci, L. (1982). New perspectives on the microvasculature of the islets of Langerhans in the rat. Diabetes, Vol. 31, pp 883-889, ISSN 1939-327X

Bonner-Weir, S. (2000). Perspective: Postnatal pancreatic beta cell growth. Endocrinology, Vol. 141, pp 1926-1929, ISSN 1945-7170

Bonner-Weir S, \& Sharma A. (2002). Pancreatic stem cells. J Pathol, Vol. 197, pp 519-526, ISSN 0022-3417

Bonner-Weir, S., \& Sharma, A. (2006). Are there pancreatic progenitor cells from which new islets form after birth? Nat Clin Pract Endocrinol Metab., Vol. 2, pp 240-241, ISSN 1759-5029

Bonner-Weir, S. (1993) The pancreas. Biology, pathobiology and disease. The microvasculature of the pancreas, with special emphasis on that of the islets of Langerhans. Anatomy and functional implications, Go V.L.W., Dimagno E.P., Gardner J.D., Lebenthal E., Reber H.A., Scheele G.A., (Ed.), pp 759-768. Raven Press, New York.

Brissova, M., Shostak, A., Shiota, M., Wiebe, P.O., Poffenberger, G., Kantz, J., Chen, Z., Carr, C., Jerome, W.G., Chen, J., Baldwin, H., Nicholson, W. Bader, D., Jetton, T., Gannon, M., \& Powers, A.C. (2006) Pancreatic islet production of vascular endothelial 
growth factor--a is essential for islet vascularization, revascularization, and function. Diabetes. Vol. 55, pp 2974-85, ISSN 1939-327X

Brunicardi, F.C., Stagner, J., Bonner-Weir, S., Wayland, H., Kleinman, R., Livingston, E., Guth, P., Menger, M., McCuskey, R., Intaglietta, M., Charles, A., Ashley, S., Cheung, A., Ipp, E., Gilman, S., Howard, T., \& Passaro E. Jr. (1996). Microcirculation of the islets of Langerhans. Diabetes, Vol. 45, pp 385-392, ISSN 1939-327X

Carson, S. D., Hobbs, J. T., Tracy, S. M., \& Chapman, N. M. (1999). Expression of the coxsackievirus and adenovirus receptor in cultured human umbilical vein endothelial cells: regulation in response to cell density. J. Virol., Vol. 73, pp 70777079, ISSN 1098-5514

Chakrabarti, D., Hultgren, B., \& Stewart, T. A. (1996). IFN-alpha induces autoimmune T cells through the induction of intracellular adhesion molecule-1 and B7.2. J. Immunol, Vol. 157, pp 522-528, ISSN 1550- 6606

Charakida, M., Donald, A. E., Terese, M., Leary, S., Halcox, J. P., Ness, A., Smith, G. D., Golding, J., Friberg, P., Klein, N. K., \& Deanfield JE; ALSPAC (Avon Longitudinal Study of Parents and Children) Study Team. (2005). Endothelial dysfunction in childhood infection. Circulation, Vol. 111, pp 1660-1665, ISSN 0009-7322

Charo, I.F., Shak, S., Karasek, M.A., Davison, P., \& Goldstein, I.M. (1984). Prostaglandin I2 is not a major metabolite of arachidonic acid in cultured endothelial cells from human foreskin microvessels. J Clin Invest, Vol. 7, pp 914-919, ISSN 1558-8238

Chatterjee, N.K., Nejman, C., \& Gerling, I.. (1988). Purification and characterization of a strain of coxsackievirus B4 of human origin that induces diabetes in mice. J Med Virol, Vol. 26, pp 57-69, ISSN 1096-9071

Chehadeh, W., Kerr-Conte, J., Pattou, F., Alm, G., Lefebvre, J., Wattre, P., \& Hober, D. (2000). Persistent infection of human pancreatic islets by coxsackievirus B is associated with alpha interferon synthesis in beta cells. J Virol, Vol. 74, pp 10153-10164, ISSN 1098-5514

Chehadeh, W., Weill, J., Vantyghem, M.C., Alm, G., Lefèbvre, J., Wattré, P., \& Hober, D. (2000). Increased level of interferon-alpha in blood of patients with insulindependent diabetes mellitus: relationship with coxsackievirus B infection. J Infect Dis, Vol. 181, pp 1929-1939, ISSN 1344-6304

Choy, J.C., Granville, D.J., Hunt, D.W., \& McManus, B.M. (2001). Endothelial cell apoptosis: biochemical characteristics and potential implications for atherosclerosis. J Mol Cell Cardiol, Vol. 33, pp 1673-1690, ISSN 0022-2828

Clements, G.B., Galbraith, D.N., \& Taylor, K.W. (1995). Coxsackie B virus infection and onset of childhood diabetes. Lancet, Vol. 346, pp 221-223, ISSN 0140-6736

Cnop, M., Hughes, S.J., Igoillo-Esteve, M., Hoppa, M.B., Sayyed, F., van de Laar, L., Gunter, J.H., de Koning, E.J., Walls, G.V., Gray, D.W., Johnson, P.R., Hansen, B.C., Morris, J.F., Pipeleers-Marichal, M., Cnop, I., \& Clark, A. (2009). The long lifespan and low turnover of human islet beta cells estimated by mathematical modelling of lipofuscin accumulation. Diabetologia, Vol. 53, pp 321-330, ISSN 0012-186X

Conaldi, P. G., Serra, C., Mossa, A., Falcone, V., Basolo, F., Camussi, G., Dolei, A., \& Toniolo, A. (1997) Persistent infection of human vascular endothelial cells by Group B Coxsackieviruses. J. Infect. Dis., Vol. 175, pp 693-696, ISSN 1344-6304 
Corbett, J.A., Sweetland, M.A., Wang, J.L., Lancaster, J.R., \& McDaniel. M.L. (1993). Nitric oxide mediates cytokine-induced inhibition of insulin secretion by human islets of Langerhans. Proc Natl Acad Sci USA, Vol. 90, pp 1731-1735, ISSN 0027-8424

Coyne, C.B., \& Bergelson, J.M. (2006). Virus-induced Abl and Fyn kinase signals permit coxsackievirus entry through epithelial tight junctions. Cell, Vol. 124, pp 119-131, ISSN 0092-8674

D'Amore, P.A., \& Ng, Y.S. (2002). Won't you be my neighbour? Local induction of arteriogenesis. Cell, Vol. 110, pp 289-292, ISSN 0092-8674

Datta, S.R., Brunet, A., \& Greenberg, M.E. (1999). Cellular survival: a play in three Akts. Genes Dev, Vol. 13, pp 2905-2927, ISSN 1549-5477

Di Lorenzo, T.P., Peakman, M., \& Roep, B.O. (2007). Translational mini-review series on type 1 diabetes: Systematic analysis of T cell epitopes in autoimmune diabetes. Clin Exp Immunol, Vol. 148, pp 1-16, ISSN 1365-2249

Dor, Y., Brown, J., Martinez, O.I., \& Melton, D.A. (2004). Adult pancreatic beta-cells are formed by self-duplication rather than stem-cell differentiation. Nature, Vol. 429(6987), pp 41-46 ISSN 0028-0836

Dotta, F., Censini, S., van Halteren, A.G., Marselli, L., Masini, M., Dionisi, S., Mosca, F., Boggi, U., Muda, A.O., Del Prato, S., Elliott, J.F., Covacci, A., Rappuoli, R., Roep, B.O., \& Marchetti, P. (2007). Coxsackie B4 virus infection of $\beta$ cells and natural killer cell insulitis in recent-onset type 1 diabetic patients. Proc Natl Acad Sci U S A, Vol. 104, pp 5115-5120, ISSN 0027-8424

Elghazi, L., Balcazar, N., \& Bernal-Mizrachi, E. (2006). Emerging role of protein kinase B/Akt signaling in pancreatic beta-cell mass and function. Int J Biochem Cell Biol, Vol. 38, pp 157-163, ISSN 1357-2725

Epperson, D.E., \& Pober, J.S. (1994). Antigen-presenting function of human endothelial cells. Direct activation of resting CD8 T cells. J Immunol, Vol. 153, pp 5402-5412, ISSN 1550- 6606

Ercolini, A.M., \& Miller, S.D. (2009). The role of infections in autoimmune disease. Clin Exp Immunol, Vol. 155, pp 1-15, ISSN 1365-2249

Favaro, E., Bottelli, A., Lozanoska-Ochser, B., Ferioli, E., Huang, G.C., Klein, N., Chiaravalli, A., Perin, P.C., Camussi, G., Peakman, M., Conaldi, P.G., \& Zanone, M.M. (2005). Primary and immortalised human pancreatic islet endothelial cells: phenotypic and immunological characterisation. Diabetologia, Vol. 48, pp 2552-2562, ISSN ISSN 0012-186X

Favaro, E., Miceli, I., Bussolati, B., Schmitt-Ney, M., Cavallo Perin, P., Camussi, G., \& Zanone, M.M. (2008). Hyperglycemia induces apoptosis of human pancreatic islet endothelial cells: effects of pravastatin on the Akt survival pathway. Am J Pathol, Vol. 173, pp 442-450, ISSN 0887-8005

Favaro, E. ,Miceli, I. , Settanni, F., Baragli, A., Granata, R., Camussi, G., Ghigo, E., Cavallo Perin, P., \& Zanone, M.M. (2010). Obestatin and ghrelin bind to human pancreatic islet endothelial cells ad inhibit apoptosis in high glucose condition. Diabetologia, Vol. 53, [Suppl1]S1-S55, pp 14, ISSN 0012-186X

Fechner, H., Noutsias, M., Tschoepe, C., Hinze, K., Wang, X., Escher, F., Pauschinger, M., Dekkers, D., Vetter, R., Paul, M., Lamers, J., Schultheiss, H.P., \& Poller, W.(2003). Induction of Coxsackievirus-adenovirus receptor expression during myocardial tissue formation and remodelling. Circulation, Vol. 107, pp 876-882, ISSN $0009-7322$ 
Feldman, A. M. (2000). Medical progress: myocarditis. N. Engl. J. Med., Vol. 343, pp 13881398, ISSN 1533-4406

Flickinger, B.D., \& Olson, M.S. (1999). Localization of the platelet-activating factor receptor to rat pancreatic microvascular endothelial cells. Am J Pathol, Vol. 154, pp 13531358, ISSN 0887-8005

Folkman, J., Haudenschild, C., \& Zetter, B.R. (1979). Long term culture of capillary endothelial cells. Proc Natl Acad Sci USA, Vol. 76, pp 5217, ISSN 0027-8424

Flodstrom, M., Maday, A., Balakrishna, D., Cleary, M. M., Yoshimura, A., \& Sarvetnick., N. (2002). Target cell defense prevents the development of diabetes after viral infection. Nat. Immunol, Vol. 3, pp 373-382, ISSN 1529-2908

Flodström, M., Tsai, D., Fine, C., Maday, A., \& Sarvetnick, N. (2003). Diabetogenic potential of human pathogens uncovered in experimentally permissive beta-cells. Diabetes, Vol. 52, pp 2025-2034, ISSN 1939-327X

Foulis, A.K., Farquharson, M.A., Meager, A. (1987). Immunoreactive alpha-interferon in insulin-secreting beta cells in type 1 diabetes mellitus. Lancet, Vol. 2, pp 1423-1427, ISSN 0140-6736

Foulis, A.K., McGill, M., Farquharson, M.A., \& Hilton, D.A. (1997). A search for evidence of viral infection in pancreases of newly diagnosed patients with IDDM. Diabetologia, Vol. 40, pp 53-61, ISSN 0012-186X

Friedman, H.M., Macarak, E. J., MacGregor, R.R., Wolfe, J.A., \& Kefalides, N.A. (1981) Virus infection of endothelial cells. J. Infect. Dis., Vol. 143, pp 266-273, ISSN 1344-6304

Füchtenbusch, M., Irnstetter, A., Jäger, G., \& Ziegler, A.G. (2001). No evidence for an association of Coxsackie virus infections during pregnancy and early childhood with development of islet autoantibodies in offspring of mothers or fathers with type 1 diabetes. J Autoimmun, Vol. 17, pp 333-340, ISSN 0896-8411

Fujimoto, T., \& Singer, S.J. (1988). Immunochemical studies of endothelial cells in vivo: II. Chicken aortic and capillary endothelial cells exhibit different cell-surface distributions of the integrin complex. J Histochem Cytochem, Vol. 36, pp 1309-1317, ISSN 0022-1554

Fuse, K., Chan, G., Liu, Y., Gudgeon, P., Husain, M., Chen, M., Yeh, W.C., Akira, S., \& Liu, P.P. (2005). Myeloid differentiation factor-88 plays a crucial role in the pathogenesis of Coxsackievirus B3-induced myocarditis and influences type I interferon production. Circulation, Vol. 112, pp 2276-2285, ISSN 0009-7322

Graves, P.M., Rotbart, H.A., Nix, W.A., Pallansch, M.A., Erlich, H.A., Norris, J.M., Hoffman, M., Eisenbarth, G.S., \& Rewers, M. (2003). Prospective study of enteroviral infections and development of beta-cell autoimmunity: Diabetes Autoimmunity Study in the Young (DAISY). Diabetes Res Clin Pract, Vol. 59, pp 51-61, ISSN 01688227

Green, J., Casabonne, D., \& Newton, R. (2004). Coxsackie B virus serology and Type 1 diabetes mellitus: a systematic review of published case-control studies. Diabet Med, Vol. 21, pp 507-514, ISSN 1464-5491

Greening, J.E., Tree, T.I., Kotowicz, K.T., van Halteren, A.G., Roep, B.O., Klein, N.J., \& Peakman M. (2003). Processing and presentation of the islet autoantigen GAD by vascular endothelial cells promotes transmigration of autoreactive T-cells. Diabetes, Vol. 52, pp 717-725, ISSN 1939-327X 
Hanafusa, T., Miyazaki, A., Miyagawa, J., Tamura, S., Inada, M., Yamada, K., Shinji, Y., Katsura, H., Yamagata, K., Itoh, N., \& et al. (1990). Examination of islets in the pancreas biopsy specimens from newly diagnosed type 1 (insulin-dependent) diabetic patients. Diabetologia, Vol. 33, pp 105-111, ISSN 0012-186X

Hanninen, A., Jalkanen, S., Salmi, M., Toikkanen, S., Nikolakaros, G., \& Simell, O. (1992). Macrophages, $\mathrm{T}$ cell receptor usage, and endothelial cell activation in the pancreas at the onset of insulin-dependent diabetes mellitus. J Clin Invest, Vol. 90, pp 19011910, ISSN 0021-9738

Hänninen, A., Salmi, M., Simell, O., \& Jalkanen, S. (1993). Endothelial cell-binding properties of lymphocytes infiltrated into human diabetic pancreas. Implications for pathogenesis of IDDM. Diabetes, Vol. 42, pp 1656-1662, ISSN 1939-327X

Hartig, P.C., Madge, G.E., \& Webb S.R. (1983). Diversity within a human isolate of coxsackie B4: relationship to viral-induced diabetes. J Med Virol., Vol. 11, pp 23-30, ISSN 10969071

Hedrick, J. A., Saylor, V., Figueroa, D., Mizoue, L., Xu, Y., Menon, S., Abrams, J., Handel, T., \& Zlotnik, A. (1997). Lymphotactin is produced by NK cells and attracts both NK cells and T cells in vivo. J. Immunol., Vol. 158, pp 1533-1540, ISSN 1550- 6606

Heim, A., Canu, A., Kirschner, P., Simon, T., Mall, G., Hofschneider, P. H., \& Kandolf, R. (1992). Synergistic interaction of interferon-beta and interferon-gamma in coxsackievirus B3-infected carrier cultures of human myocardial fibroblasts. J. Infect. Dis., Vol. 166, pp 958-965, ISSN 1344-6304

Henningsson, R., Salehi, A., \& Lundquist, I. (2002). Role of nitric oxide synthase isoforms in glucose-stimulated insulin release. Am J Physiol Cell Physiol, Vol. 283, pp 296-304, ISSN 1522-1563.

Henderson, J.R., \& Moss, M.C. (1985). A morphometric study of the endocrine and exocrine capillaries of the pancreas. Q J Exp Physiol, Vol. 70, pp 347-356, ISSN 0144-8757

Hiltunen, M., Hyöty, H., Knip, M., Ilonen, J., Reijonen, H., Vähäsalo, P., Roivainen, M., Lonnrot, M., Leinikki, P., Hovi, T., \& Akerblom H.K. (1997). Islet cell antibody seroconversion in children is temporally associated with enterovirus infections. $J$ Infect Dis, Vol. 175, pp 554-560, ISSN 1344-6304

Hingorani, A.D., Cross, J.C., Kharbanda, R.K., Mullen, M.J., Bhagat, K., Taylor, M., Donald, A.E., Palacios, M., Griffin, G. E., Deanfield, J.E., MacAllister, R.J., \& Vallance, P. (2000). Acute systemic inflammation impairs endothelium-dependent dilatation in humans. Circulation, Vol. 102, pp 994-999, ISSN 0009-7322

Homann, D., Jahreis, A., Wolfe, T., Hughes, A., Coon, B., van Stipdonk, M.J., Prilliman, K.R., Schoenberger, S.P., \& von Herrath, M.G. (2002). CD40L blockade prevents autoimmune diabetes by induction of bitypic NK/DC regulatory cells. Immunity, Vol. 16, pp 403-415, ISSN 1074-7613

Honeyman, M.C., Coulson, B.S., Stone, N.L., Gellert, S.A., Goldwater, P.N., Steele, C.E., Couper, J.J., Tait, B.D., Colman, P.G., \& Harrison, L.C. (2000). Association between rotavirus infection and pancreatic islet autoimmunity in children at risk of developing type 1 diabetes. Diabetes, Vol. 49, pp 1319-1324, ISSN 1939-327X

Horwitz, M. S., Bradley, L. M., Harbertson, J., Krahl, T., Lee, J., \& Sarvetnick, N. (1998) Diabetes induced by Coxsackie virus: initiation by bystander damage and not molecular mimicry. Nature Med., Vol. 4, pp 781-785, ISSN 1078-8956 
Huang, X., Yuang, J., Goddard, A., Foulis, A., James, R. F., Lernmark, A., Pujol-Borrell, R., Rabinovitch, A., Somoza, N., \& Stewart, T. A. (1995). Interferon expression in the pancreases of patients with type I diabetes. Diabetes, Vol. 44, pp 658-664, ISSN 1939$327 X$

Huber, S.A., Haisch, C., \& Lodge, P. A. (1990) Functional diversity in vascular endothelial cells: role in Coxsackievirus tropism. J. Virol., Vol. 64, pp 4516-4522, ISSN 1098-5514

Huber, S.A. (2006). Autoimmunity in coxsackievirus B3 induced myocarditis. Autoimmunity, Vol. 39, pp 55-61, ISSN 0891-6934

Huber, T.B., Hartleben, B., Kim, J., Schmidts, M., Schermer, B., Keil, A., Egger, L., Lecha, R.L., Borner, C., Pavenstädt, H., Shaw, A.S., Walz, G., \& Benzing, T. (2003). Nephrin and CD2AP associate with phosphoinositide 3-OH kinase and stimulate AKTdependent signaling. Mol Cell Biol., Vol. 23, pp 4917-28, ISSN 1098-5549

Hyöty, H., Leinikki, P., Reunanen, A., Ilonen, J., Surcel, H.M., Rilva, A., Käär, M.L., Huupponen, T., Hakulinen, A., Mäkelä, A.L., \& et al. (1988). Mumps infections in the etiology of type 1 (insulin-dependent) diabetes. Diabetes Res, Vol. 9, pp 111-116, ISSN 0265-5985

Hyöty, H., \& Taylor, K. W. (2002). The role of viruses in human diabetes. Diabetologia, Vol. 45, pp 1353-1361, ISSN 0012-186X

Itoh, N., Hanafusa, T., Miyazaki, A., Miyagawa, J., Yamagata, K., Yamamoto, K., Waguri, M., Imagawa, A., Tamura, S., Inada, M., \& et al. (1993). Mononuclear cell infiltration and its relation to the expression of major histocompatibility complex antigens and adhesion molecules in pancreas biopsy specimens from newly diagnosed insulindependent diabetes mellitus patients. J Clin Invest, Vol. 92, pp 2313-2322, ISSN 00219738

Ito, M., Kodama, M., Masuko, M., Yamaura, M., Fuse, K., Uesugi, Y., Hirono, S., Okura, Y., Kato, K., Hotta, Y., Honda, T., Kuwano, R., \& Aizawa, Y. (2000). Expression of coxsackievirus and adenovirus receptor in hearts of rats with experimental autoimmune myocarditis. Circ Res, Vol. 86, pp 275-280, ISSN 0009-7300

Johansson, M., Mattsson, G., Andersson, A., Jansson, L., \& Carlsson, P.O. (2006). Islet endothelial cells and pancreatic beta-cell proliferation: studies in vitro and during pregnancy in adult rats. Endocrinology, Vol. 147, pp 2315-2324, ISSN 1945-7170

Jung, F., Haendeler, J., Goebel, C., Zeiher, A.M., \& Dimmeler, S. (2000). Growth factorinduced phosphoinositide 3-OH kinase/Akt phosphorylation in smooth muscle cells: induction of cell proliferation and inhibition of cell death. Cardiovasc Res, Vol. 48, pp 148-157, ISSN 1755-3245

Kallewaard, N.L., Zhang, L., Chen, J.W., Guttenberg, M., Sanchez, M.D., \& Bergelson, J.M. (2009). Tissue-specific deletion of the coxsackievirus and adenovirus receptor protects mice from virus-induced pancreatitis and myocarditis. Cell Host Microbe, Vol. 23;6, pp 91-98, ISSN 1931-3128

Karin, M., Liu, Z., \& Zandi, E. (1997). AP-1 function and regulation. Curr Opin Cell Biol, Vol. 9, pp 240-246, ISSN 0955-0674

Karvonen, M., Tuomilehto, J., Libman, I., \& LaPorte, R. (1993). A review of the recent epidemiological data on the worldwide incidence of type 1 (insulin-dependent) diabetes mellitus. World Health Organization DIAMOND Project Group. Diabetologia, Vol. 36, pp 883-892, ISSN 0012-186X 
Kay, T.W., Campbell, I.L., Oxbrow, L., \& Harrison, L.C. (1991). Overexpression of class I major histocompatibility complex accompanies insulitis in the non-obese diabetic mouse and is prevented by anti-interferon-gamma antibody. Diabetologia, Vol. 34, pp 779-785, ISSN 0012-186X

Kennedy, J., Kelner, G.S., Kleyensteuber, S., Schall, T.J., Weiss, M.C., Yssel, H., Schneider, P.V., Cocks, B.G., Bacon, K.B., \& Zlotnik, A. (1995). Molecular cloning and functional characterization of human lymphotactin. J. Immunol., Vol. 155, pp 203209, ISSN 1550- 6606

King, A.M.Q. , Brown, F.,Christian, P., Hovi, T. ,Hyypiä, T., Knowles, N.J., \& et al., (2002). Family Picornaviridae. In: M.H.V. Van Regenmortel, C.M. Fauquet, D.H.L. Bishop, C.H. Calisher and E.B. Carsten et al., Editors, Virus Taxonomy. Seventh Report of the International Committee for the Taxonomy of Viruses, Academic Press, New York, San Diego (2000), pp. 657-678.

Klingel, K., Hohenadl, C., Canu, A., Albrecht, M., Seemann, M., Mall, G., \& Kandolf, R. (1992). Ongoing enterovirus-induced myocarditis is associated with persistent heart muscle infection: quantitative analysis of virus replication, tissue damage, and inflammation. Proc. Natl. Acad. Sci. U. S. A., Vol. 89, pp 314-318, ISSN 0027-8424

Kolb, H., \& Kolb-Bachofen, V. (1992). Nitric oxide: a pathogenetic factor in autoimmunity. Immunol Today, Vol. 13, pp 157-160, ISSN 0167-4919

Konstantinova, I., \& Lammert, E. (2004). Microvascular development: learning from pancreatic islets. Bioessays, Vol. 26, pp 1069-1075, ISSN 1521-1878.

Kroncke, K.D., Kolb-Bachofen, V., Berschick, B., Burkart, V., \& Kolb, H. (1991). Activated macrophages kill pancreatic syngeneic islet cells via arginine-dependent nitric oxide generation. Biochem Biophys Res Commun, Vol. 175, pp 752-758, ISSN 0006291X

Kroncke, K.D., Rodriguez, M.L., Kolb, H., \& Kolb-Bachofen, V. (1993). Cytotoxicity of activated rat macrophages against syngeneic islet cells is arginine-dependent, correlates with citrulline and nitrite concentrations and is identical to lysis by the nitric oxide donor nitroprusside. Diabetologia, Vol. 36, pp 17-24, ISSN 0012-186X

Kubota, Y., Kleinman, H., Martin, G.R., \& Lawley, T.J. (1988). Role of laminin and basement in the differentiation of human endothelial cells into capillary-like structures. J Cell Biol, Vol. 107, pp 1589-1598, ISSN 1540-8140

Lammert, E., Cleaver, O., \& Melton, D. (2001). Induction of pancreatic differentiation by signals from blood vessels. Science, Vol. 294, pp 564-567, ISSN 1095-9203

Lammert, E., Gu, G., McLaughlin, M., Brown D., Brekken, R., Murtaugh, L.C., Gerber, H.P., Ferrara, N., \& Melton D.A. (2003). Role of VEGF-A in vascularization of pancreatic islets. Curr Biol, Vol. 13, pp 1070-1074, ISSN 0960-9822

Lee, K.H., Lawley, T.J., Xu, Y., \& Swerlick, R.A. (1992). VCAM-1, ELAM-1, and ICAM-1 independent adhesion of melanoma cells to cultured human dermal microvascular endothelial cells. J Invest Dermatol, Vol. 98, pp 79, ISSN 0022-202X

Lidington, E.A., Moyes, D.L., McCormack, A.M., \& Rose, M.L. (1999). A comparison of primary endothelial cells and endothelial cell lines for studies of immune interactions. Transpl Immunol, Vol. 7, pp 239-246, ISSN 0966-3274,

Like, A.A. (1970). The uptake of exogenous peroxidase by the beta cells of the islets of Langerhans. Am J Pathol, Vol. 59, pp 225-246, ISSN 0887-8005 
Liu, S., Wang, H., Jin, Y., Podolsky, R., Reddy, M.V., Pedersen, J., Bode, B., Reed, J., Steed, D., Anderson, S., Yang, P., Muir, A., Steed, L., Hopkins, D., Huang, Y., Purohit, S., Wang, C.Y., Steck, A.K., Montemari, A., Eisenbarth, G., Rewers, M., \& She, J.X. (2009). IFIH1 polymorphisms are significantly associated with type 1 diabetes and IFIH1 gene expression in peripheral blood mononuclear cells. Hum Mol Genet, Vol. 15;18, pp 358-365, ISSN 0964-6906

Lönnrot, M., Knip, M., Roivainen, M., Koskela, P., Åkerblom, H.K., \& Hyöty, H. (1998). Onset of type I diabetes in infancy after enterovirus infections. Diab Med, Vol. 15, pp 431-434, ISSN 1464-5491.

Lönnrot, M., Salminen, K., Knip, M., Savola, K., Kulmala, P., Leinikki, P., Hyypiä, T., Åkerblom, H.K., \& Hyöty, H. (2000). the Childhood Diabetes in Finland (DiMe) Study Group. Enterovirus RNA in serum is a risk factor for beta-cell autoimmunity and clinical type 1 diabetes: a prospective study. J Med Virol, Vol. 61, pp 214-220, ISSN 1096-9071

Lönnrot, M., Korpela, K., Knip, M., Ilonen, J., Simell, O., Korhonen, S., Savola, K., Muona, P., Simell, T., Koskela, P., \& Hyöty, H. (2000). Enterovirus infection as a risk factor for beta-cell autoimmunity in a prospectively observed birth cohort: the Finnish Diabetes Prediction and Prevention Study. Diabetes, Vol. 49, pp 1314-1318, ISSN 1939-327X

Lozanoska-Ochser, B., \& Peakman, M. (2005). CD86 on resting human islet endothelial cells co-stimulates CD4 T cell activation and facilitates T cell trans-endothelial migration in vitro. Endocrine Journal, Vol. 52 Suppl: 82, ISSN 0918-8959.

Luppi, P., Rudert, W. A., Zanone, M. M., Stassi, G., Trucco, G., Finegold, D., Boyle, G. J., del Nido, P., McGowan, F. X., \& Trucco, M. (1998) Idiopathic dilated cardiomyopathy: a superantigen-driven autoimmune disease. Circulation, Vol. 98, pp 777-785, ISSN 0009-7322

Luppi, P., Zanone, M.M., Hyoty, H., Rudert, W.A., Haluszczak, C., Alexander, A.M., Bertera, S., Becker, D., \& Trucco, M. (2000). Restricted TCR V beta gene expression and enterovirus infection in type I diabetes: a pilot study. Diabetologia, Vol. 43, pp 1484-1497, ISSN 0012-186X

Maedler, K., Sergeev, P., Ris, F., Oberholzer, J., Joller-Jemelka, H.I., Spinas, G.A., Kaiser, N., Halban, P.A. \& Donath, M.Y. (2002). Glucose-induced beta cell production of IL1 beta contributes to glucotoxicity in human pancreatic islets. J Clin Invest, Vol. 110 pp 851-860, ISSN:0021-9738

Mach, F., Schönbeck, U., Sukhova, G.K., Bourcier, T., Bonnefoy, J.Y., Pober, J.S., \& Libby, P. (1997). Functional CD40 ligand is expressed on human vascular endothelial cells, smooth muscle cells, and macrophages: implications for CD40-CD40 ligand signaling in atherosclerosis. Proc Natl Acad Sci U S A , Vol. 94, pp 1931-1936, ISSN 0027-8424

Marelli-Berg, F.M., Frasca, L., Weng, L., Lombardi, G., \& Lechler, R.I. (1999). Antigen recognition influences transendothelial migration of CD4+ T cells. J Immunol, Vol. 162, pp 696-703, ISSN 1550- 6606

Marelli-Berg, F.M., James, M.J., Dangerfield, J., Dyson, J., Millrain, M., Scott, D., Simpson, E., Nourshargh, S., \& Lechler, R.I. (2004). Cognate recognition of the endothelium induces HY-specific CD8+ T-lymphocyte transendothelial migration (diapedesis) in vivo. Blood, Vol. 103, pp 3111-3116, ISSN 1528-0020 
Mattsson, G., Danielsson, A., Kriz, V., Carlsson, P.O., \& Jansson, L. (2006). Endothelial cells in endogenous and transplanted pancreatic islets: differences in the expression of angiogenic peptides and receptors. Pancreatology, Vol. 6, pp 86-95, ISSN 1424-3911

Meier, J.J. (2008). Beta cell mass in diabetes: a realistic therapeutic target? Diabetologia, Vol. 51, pp 703-713, ISSN 0012-186X

Meier, J.J., Butler, A.E., Saisho, Y., Monchamp, T., Galasso, R., Bhushan, A., Rizza, R.A., Butler, \& P.C. (2008). Beta-cell replication is the primary mechanism subserving the postnatal expansion of beta-cell mass in humans. Diabetes, Vol. 57, pp 1584-1594, ISSN 1939-327X

Middel, P., Thelen, P., Blaschke, S., Polzien, F., Reich, K., Blaschke, V., Wrede, A., Hummel, K.M., Gunawan, B., \& Radzun, H.J. (2001). Expression of the T-cell chemoattractant chemokine lymphotactin in Crohn's disease. Am. J. Pathol., Vol. 159, pp 1751-1761, ISSN 0887-8005

Mizuno, A., Noma, Y., Kuwajima, M., Murakami, T., Zhu, M., \& Shima, K. (1999). Changes in islet capillary angioarchitecture coincide with impaired B-cell function but not with insulin resistance in male Otsuka-Long-Evans-Tokushima fatty rats: dimorphism of the diabetic phenotype at an advanced age. Metabolism, Vol. 48, pp 477-483, ISSN 1550-4131

Muir, P., Tizley, A.J., English, T. A.H., Nicholson, F., Signey, M., \& Banatvala, J.E. (1989). Chronic relapsing pericarditis and dilated cardiomyopathy: serological evidence of persistent enterovirus infection. Lancet, Vol. 333, pp 804-807, ISSN 0140-6736.

Nejentsev, S., Walker, N., Riches, D., Egholm, M., \& Todd, J.A. (2009). Rare variants of IFIH1, a gene implicated in antiviral responses, protect against type 1 diabetes. Science, Vol. 17; pp 387-389, ISSN 1095-9203

Nikolova, G., Jabs, N., Konstantinova, I., Domogatskaya, A., Tryggvason, K., Sorokin, L., Fässler, R., Gu, G., Gerber, H.P., Ferrara, N., Melton, D.A., \& Lammert E (2006). The vascular basement membrane: a niche for insulin gene expression and Beta cell proliferation. Dev Cell, Vol. 10, pp 397-405, ISSN 1551-4005

Noutsias, M., Fechner, H., de Jonge, H., Wang, X., Dekkers, D., Houtsmuller, A.B., Pauschinger, M., Bergelson, J., Warraich, R., Yacoub, M., Hetzer, R., Lamers, J., Schultheiss, H.P., \& Poller, W.(2001). Human coxsackie-adenovirus receptor is colocalized with integrins alpha(v) beta(3) and alpha(v) beta(5) on the cardiomyocyte sarcolemma and up-regulated in dilated cardiomyopathy: implications for cardiotropic viral infections. Circulation, Vol. 104, pp 275-280, ISSN 0009-7322

Noutsias, M., Seeberg, B., Schultheiss, H. P., \& Kuhl, U. (1999). Expression of cell adhesion molecules in dilated cardiomyopathy: evidence for endothelial activation in inflammatory cardiomyopathy. Circulation, Vol. 99, pp 2124-2131, ISSN 0009-7322

Oikarinen, M., Tauriainen, S., Honkanen, T., Oikarinen, S., Vuori, K., Kaukinen, K., Rantala, I., Mäki, M., \& Hyöty, H.(2008). Detection of enteroviruses in the intestine of type 1 diabetic patients. Clin Exp Immunol, Vol. 151, pp 71-75, ISSN 0009-9104

Ono, S.J., Issa-Chergui, B., Colle, E., Guttmann, R.D., Seemayer, T.A., \& Fuks, A. (1988). IDDM in BB rats. Enhanced MHC class I heavy-chain gene expression in pancreatic islets. Diabetes, Vol. 37, pp 1411-1418, ISSN 1939-327X 
Ostermann, G., Weber, K.S., Zernecke, A., Schroder, A., \& Weber, C. (2002). JAM-1 is a ligand of the beta(2) integrin LFA-1 involved in transendothelial migration of leukocytes. Nat Immunol, Vol. 3, pp 151-8, ISSN 1529-2908

Otonkoski, T., Roivainen, M., Vaarala, O., \& et al. (2000). Neonatal type I diabetes associated with maternal echovirus 6 infection: a case report. Diabetologia. 2000, Vol. 43, pp 1235-1238, ISSN 0012-186X

Petzelbauer, P., Bender, J.R., Wilson, J., \& Pober, J.S. (1993). Heterogeneity of dermal microvascular endothelial cell antigen expression and cytokine responsiveness in situ and in cell culture. J Immunol, Vol. 151, pp 5062-5072, ISSN 1550- 6606

Pober, J.S., Kluger, M.S., \& Schechner, J.S. (2001). Human endothelial cell presentation of antigen and the homing of memory/effector T cells to skin. Ann N Y Acad Sci, Vol. 941, pp 12-25, ISSN 0077-8923

Predescu, D., Predescu, S., McQuistan, T., \& Palade, G.E. (1998). Transcytosis of alpha1acidic glycoprotein in the continuous microvascular endothelium. Proc Natl Acad Sci USA, Vol. 95, pp 6175-6180, ISSN 0027-8424

Richardson, S.J., Willcox, A., Bone, A.J., Foulis, A.K., \& Morgan, N.G. (2009). The prevalence of enteroviral capsid protein vp1 immunostaining in pancreatic islets in human type 1 diabetes. Diabetologia, Vol. 52, pp 1143-1151, ISSN 0012-186X

Roivainen, M., Rasilainen, S., Ylipaasto, P., Nissinen, R., Ustinov, J., Bouwens, L., Eizirik, D.L., Hovi, T., \& Otonkoski, T.(2000). Mechanisms of coxsackievirus-induced damage to human pancreatic beta-cells. J Clin Endocrinol Metab, Vol. 85, pp 432-440, ISSN 1945-7197

Roivainen, M., Ylipaasto, P., Savolainen, C., Galama, J., Hovi, T., \& Otonkoski, T. (2002). Functional impairment and killing of human beta cells by enteroviruses: the capacity is shared by a wide range of serotypes, but the extent is a characteristic of individual virus strains. Diabetologia, Vol. 45, pp 693-702, ISSN 0012-186X

Roivainen, M. (2006). Enteroviruses: new findings on the role of enteroviruses in type 1 diabetes. Int J Biochem Cell Biol, Vol. 38, pp 721-725, ISSN 1357-2725

Rose, N. R., Herskowitz, A., \& Neumann, D. A. (1993) Autoimmunity in myocarditis: models and mechanisms. Clin. Immunol. Immunopathol., Vol. 2, pp 95-99, ISSN 00901229

Ruotsalainen, V., Ljungberg, P., Wartiovaara, J. Lenkkeri, U., Kestilä, M., Jalanko, H., Holmberg, C., \& Tryggvason, K. (1999). Nephrin is specifically located at the slit diaphragm of glomerular podocytes. Proc Natl Acad Sci USA, Vol. 96, pp 7962-7967, ISSN 0027-8424

Sadeharju, K., Hämäläinen, A.M., Knip, M., Lönnrot, M., Koskela, P., Virtanen, S.M., Ilonen, J., Åkerblom, H.K., \& Hyöty, H. (2003). the Finnish TRIGR Study Group. Enterovirus infections as a risk factor for type I diabetes: virus analyses in a dietary intervention trial. Clin Exp Immunol, Vol. 132, pp 271-277, ISSN 0009-9104

Saijets, S., Ylipaasto, P., Vaarala, O., Hovi, T., \& Roivainen, M. (2003) Enterovirus infection and activation of human umbilical vein endothelial cells. J. Med. Virol., Vol. 70, pp 430-439, ISSN 1096-9071

Salminen, K., Sadeharju, K., Lönnrot, M., Vähäsalo, P., Kupila, A., Korhonen, S., Ilonen, J., Simell, O., Knip, M., \& Hyöty, (2003). H. Enterovirus infections are associated with the induction of $\beta$-cell autoimmunity in a prospective birth cohort study. $J$ Med Virol, Vol. 69, pp 91-98, ISSN 1096-9071 
Savinov, A.Y., Wong, F.S., \& Chervonsky, A.V. (2001). IFN-gamma affects homing of diabetogenic T cells. J Immunol., Vol. 167, pp 6637-6643, ISSN 1550- 6606

Savinov, A.Y., Wong, F.S., Stonebraker, A.C., \& Chervonsky, A.V. (2003). Presentation of antigen by endothelial cells and chemoattraction are required for homing of insulin-specific CD8+ T cells. J Exp Med, Vol. 197, pp 643-656, ISSN 1940-5901

Savinov, A.Y., Rozanov, D.V., \& Strongin, A.Y. (2007). Specific inhibition of autoimmune T cell transmigration contributes to beta cell functionality and insulin synthesis in non-obese diabetic (NOD) mice. J Biol Chem, Vol. 282, pp 32106-32111, ISSN 1083$351 X$

Schmidt, H.H., Warner, T.D., Ishii, K., Sheng, H., \& Murad, F. (1992). Insulin secretion from pancreatic B cells caused by L-arginine-derived nitrogen oxides. Science, Vol. 255, pp 721-723, ISSN 1095-9203

Seko, H., Matsuda, K., Kato, Y., Hashimoto, H., Yagita, K., Okumura, K., \& Yasaki, Y. (1993). Expression of intercellular adhesion molecule 1 in murine hearts with acute myocarditis caused by coxsackievirus B3. J. Clin. Invest., Vol. 91, pp 1327-1336, ISSN 0021-9738

Selinka, H. C., Wolde, A., Pasch, A., Klingel, K., Schnorr, J. J., Kupper, J. H., Lindberg, A. M., \& Kandolf, R. (2004). Virus-receptor interactions of coxsackie B viruses and their putative influence on cardiotropism. Med. Microbiol. Immunol, Vol. 193, pp 127-131, ISSN 1432-1831

Shafren, D.R., Bates, R.C., Agrez, M.V., Herd, R.L., Burns, G.F., \& Barry, R.D. (1995). Coxsackieviruses B1, B3, and B5 use decay accelerating factor as a receptor for cell attachment. J Virol, Vol. 69, pp 3873-3877, ISSN 1098-5514

Shafren, D. R. (1998). Viral cell entry induced by cross-linked decay-accelerating factor. J. Virol., Vol. 72, pp 9407-9412, ISSN 1098-5514

Shi, Y., Fukuoka, M., Li, G., Liu, Y., Chen, M., Konviser, M., Chen, X., Opavsky, M.A., \& Liu, P.P. (2010). Regulatory $\mathrm{T}$ cells protect mice against coxsackievirus-induced myocarditis through the transforming growth factor beta-coxsackie-adenovirus receptor pathway. Circulation, Vol. 121, pp 2624-2634, ISSN 0009-7322

Somoza, N., Vargas, F., Roura-Mir, C., Vives-Pi, M., Fernández-Figueras, M.T., Ariza, A., Gomis, R., Bragado, R., Martí, M., Jaraquemada, D., \& et al. (1994). Pancreas in recent onset insulin-dependent diabetes mellitus. Changes in HLA, adhesion molecules and autoantigens, restricted $\mathrm{T}$ cell receptor $\mathrm{V}$ beta usage, and cytokine profile. J Immunol, Vol. 153, pp 1360-1377, ISSN 1550- 6606

Southern, C., Schulster, D., \& Green, I.C. (1990). Inhibition of insulin secretion by interleukin-1 beta and tumour necrosis factor-alpha via an L-arginine-dependent nitric oxide generating mechanism. FEBS Lett, Vol. 276, pp 42-44, ISSN

Stark, G.R., Kerr, I.M., Williams, B.R., Silverman, R.H., \& Schreiber, R.D. (1988). How cells respond to interferons. Annu Rev Biochem, Vol. 67, pp 227-264, ISSN 0066-4154

Steiner, L., Kroncke, K., Fehsel, K., \& Kolb-Bachofen, V. (1997). Endothelial cells as cytotoxic effector cells: cytokine-activated rat islet endothelial cells lyse syngeneic islet cells via nitric oxide. Diabetologia, Vol. 40, pp 150-155, ISSN 0012-186X

Stene, L.C., Oikarinen, S., Hyöty, H., Barriga, K.J., Norris, J.M., Klingensmith, G., Hutton, J.C., Erlich, H.A., Eisenbarth, G.S., \& Rewers M. (2010). Enterovirus infection and progression from islet autoimmunity to type 1 diabetes: the Diabetes and 
Autoimmunity Study in the Young (DAISY). Diabetes, Vol. 59, pp 3174-3180, ISSN 1939-327X

Stewart, T. A., Hultgren, B., Huang, X., Pitts-Meek, S., Hully, J., \& MacLachlan, N. J. (1993). Induction of type I diabetes by interferon-alpha in transgenic mice. Science, Vol. 260, pp 1942-1946, ISSN 1095-9203

Stone, R. (1994). Post-polio syndrome: remembrance of virus past. Science, Vol. 264, pp 909, ISSN 1095-9203

Stork, P.J., \& Schmitt, J.M. (2002). Crosstalk between cAMP and MAP kinase signaling in the regulation of cell proliferation. Trends Cell Biol, Vol. 12, pp 258-266, ISSN 0962-8924

Suschek, C., Fehsel, K., Kroncke, K.D., Sommer, A., \& Kolb-Bachofen, V. (1994). Primary cultures of rat islet capillary endothelial cells. Constitutive and cytokine-inducible macrophagelike nitric oxide synthases are expressed and activities regulated by glucose concentration. Am J Pathol, Vol. 145, pp 685-695, ISSN 0887-8005

Swerlick, R.A., Garcia-Gonzalez, E., Kubota, Y., Xu, Y., \& Lawley, T.J. (1991). Studies of the modulation of MHC antigen and cell adhesion molecule expression on human dermal microvascular endothelial cells. J Invest Dermatol, Vol. 97, pp 190-196, ISSN 0022-202X

Swerlick, R.A., Lee, K.H., Wick, T.M., \& Lawley, T.J. (1992). Human dermal microvascular endothelial cells but not human umbilical vein endothelial cells express CD36 in vivo and in vitro. J Immunol, Vol. 148, pp 78-83, ISSN 1550- 6606

Swerlick, A.R., Lee, K.H., Li, L., Sepp, N.T., Wright Caughman, S., \& Lawley T.J. (1992). Regulation of vascular cell adhesion molecule 1 on human dermal microendothelial cells. J Immunol, Vol. 149, pp 698-705, ISSN 1550- 6606

Takahashi, N., Kishimoto, T., Nemoto, T., Kadowaki, T., \& Kasai, H. (2002). Fusion pore dynamics and insulin granule exocytosis in the pancreatic islet. Science, Vol. 297, pp 1349-1352, ISSN 1095-9203

Tam, P.E. (2006). Coxsackievirus myocarditis: interplay between virus and host in the pathogenesis of heart disease. Viral Immunol, Vol. 19, pp 133-146, ISSN 0882-8245

Tauriainen, S., Oikarinen, M., Keim, J., Oikarinen, S., \& Hyöty, H. the nPOD Study Group. (2009). Detection of enterovirus in pancreatic tissues of cadaver organ donors: results from the Network for Pancreatic Organ Donors with Diabetes (nPOD) study. Abstract presented at the 10th International Congress of the Immunology of Diabetes Society, 17-20 May 2009, Malmö, Sweden

Tauriainen, S., Oikarinen, S., Oikarinen, M., \& Hyöty, H. (2010). Enteroviruses in the pathogenesis of type 1 diabetes. Semin Immunopathol. 28 April 2010

Tough, D. F., \& Sprent, J. (1996). Viruses and T cell turnover: evidence for bystander proliferation. Immunol. Rev, Vol. 150, pp 129-142, ISSN 1600-065X

Treutelaar, M.K., Skidmore, J.M., Dias-Leme, C.L., Hara, M., Zhang, L., Simeone, D., Martin, D.M., \& Burant, C.F. (2003). Nestin-lineage cells contribute to the microvasculature but not endocrine cells of the islet. Diabetes, Vol. 52, pp 2503-2512, ISSN 1939-327X

Tryggvason, K., \& Wartiovaara, J. (2001). Molecular basis of glomerular permselectivity. Curr Opin Nephrol Hypertens, Vol. 10, pp 543-549, ISSN 1062-4821

Varela-Calvino, R., Sgarbi, G., Wedderburn, L.R., Dayan, C.M., Tremble, J., \& Peakman, M. (2001). T cell activation by coxsackievirus B4 antigens in type 1 diabetes mellitus: evidence for selective TCR Vbeta usage without superantigenic activity. J Immunol, Vol. 167, pp 3513-3520, ISSN 1550- 6606 
Varela-Calvino, R., \& Peakman, M. (2003). Enteroviruses and type 1 diabetes. Diabetes Metab Res Rev, Vol. 19, pp 431-441, ISSN 1520-7552

von Andrian U.H., \& Mackay, C.R. (2000). T-cell function and migration. Two sides of the same coin. N Engl J Med, Vol. 343, pp 1020-1034, ISSN 1533-4406

von Herrath, M. (2009). Can we learn from viruses how to prevent type 1 diabetes? The role of viral infections in the pathogenesis of type 1 diabetes and the development of novel combination therapies. Diabetes, Vol. 58, pp 2-11, ISSN 1939-327X

Vreugdenhil, G.R., Wijnands, P.G., Netea, M.G., van der Meer, J.W., Melchers, W.J., \& Galama, J.M. (2000). Enterovirus-induced production of pro-inflammatory and Thelper cytokines by human leukocytes. Cytokine, Vol. 12, pp 1793-1796, ISSN 10434666.

Wagner, A.H., Güldenzoph, B., Lienenlüke, B., \& Hecker, M. (2004). CD154/CD40-mediated expression of CD154 in endothelial cells: consequences for endothelial cellmonocyte interaction. Arterioscler Thromb Vasc Biol, Vol. 24, pp 715-720, ISSN 10498834

Ward, K.P., \& Galloway, W.H. (1979). Auchterlonie IA. Congenital cytomegalovirus infection and diabetes. Lancet, Vol. 1, pp 497, ISSN 0140-6736

Welsh, N., \& Sandler, S. (1992). Interleukin-1 beta induces nitric oxide production and inhibits the activity of aconitase without decreasing glucose oxidation rates in isolated mouse pancreatic islets. Biochem Biophys Res Commun, Vol. 182, pp 333-340, ISSN 0006-291X

Williams, C.H., Oikarinen, S., Tauriainen, S., Salminen, K., Hyöty, H., \& Stanway, G. (2006). Molecular analysis of an echovirus 3 strain isolated from an individual concurrently with appearance of islet cell and IA-2 autoantibodies. J Clin Microbiol, Vol. 44, pp 441-448, ISSN 1098-660X

Wucherpfennig, K. W. (2001) Mechanisms for the induction of autoimmunity by infectious agents. J. Clin. Invest., Vol. 108, pp 1097-1104, ISSN 0021-9738.

Yang, Y., \& Wilson, J.M. (1996). CD40 ligand-dependent T cell activation: requirement of B7CD28 signaling through CD40. Science, Vol. 273, pp 1862-1864, ISSN 1095-9203

Ylipaasto, P., Klingel, K., Lindberg, A.M., Otonkoski, T., Kandolf, R., Hovi, T., \& Roivainen, M. (2004). Enterovirus infection in human pancreatic islet cells, islet tropism in vivo and receptor involvement in cultured islet beta cells. Diabetologia, Vol. 47, pp 225239, ISSN 0012-186X

Yoon, J.W., Onodera, T., \& Notkins, A.L. (1978). Virus-induced diabetes mellitus. XV. Beta cell damage and insulin-dependent hyperglycemia in mice infected with coxsackie virus B4. J Exp Med, Vol. 148, pp 1068-1080, ISSN 1940-5901

Yoon, J.W., Austin, M., Onodera, T., \& Notkins, A.L. (1979). Isolation of a virus from the pancreas of a child with diabetic ketoacidosis. N Engl J Med, Vol. 300, pp 1173-1179, ISSN 1553-2712

Yoshitomi, H., \& Zaret, K.S. (2004). Endothelial cell interactions initiate dorsal pancreas development by selectively inducing the transcription factor Ptf1a. Development, Vol. 131, pp 807-817, ISSN 1011-6370.

Zanone, M. M., Favaro, E., Conaldi, P. G., Greening, J., Bottelli, A., Cavallo Perin, P., Klein, N. J., Peakman, M., \& Camussi, G. (2003) Persistent infection of human microvascular endothelial cells by Coxsackie B viruses induces increased expression of adhesion molecules. J. Immunol., Vol. 171, pp 438-446, ISSN 1550- 6606 
Zanone, M.M., Favaro, E., Doublier, S., Lozanoska-Ochser, B., Deregibus, M.C., Greening, J., Huang, G.C., Klein, N., Cavallo Perin, P., Peakman, M., \& Camussi, G. (2005). Expression of nephrin by human pancreatic islet endothelial cells. Diabetologia, Vol. 48, pp 1789-1797, ISSN 0012-186X

Zanone, M.M., Favaro, E., Ferioli, E., Huang, G.C., Klein, N.J., Perin, P.C., Peakman, M., Conaldi, P.G., \& Camussi, G. (2007). Human pancreatic islet endothelial cells express Coxsackievirus and Adenovirus receptor and are activated by Coxsackie B virus infection. Faseb J, Vol. 21, pp 3308-3317, ISSN 1530-6860

Zanone, M.M., Favaro, E., \& Camusi, G. From endothelial to beta cells: insights into pancreatic islet microendothelium. (2008). Curr Diabetes Rev. Vol 4 pp 1-9, ISSN: 1066-9442

Zautner, A.E., Körner, U., Henke, A., Badorff, C., \& Schmidtke, M. (2003). Heparan sulfates and coxsackievirus-adenovirus receptor: each one mediates coxsackievirus B3 PD infection. J Virol, Vol. 77, pp 10071-10077, ISSN 1098-5514

Zheng, L., Dengler, T.J., Kluger, M.S., Madge, L.A., Schechner, J.S., Maher, S.E., Pober, J.S., \& Bothwell, A.L. (2000). Cytoprotection of human umbilical vein endothelial cells against apoptosis and CTL-mediated lysis provided by caspase-resistant Bcl-2 without alterations in growth or activation responses. J Immunol, Vol. 164, pp 46654671, ISSN 1550- 6606 


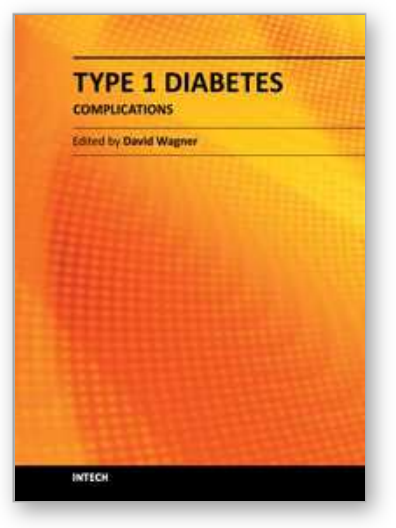

\author{
Type 1 Diabetes Complications \\ Edited by Prof. David Wagner
}

ISBN 978-953-307-788-8

Hard cover, 482 pages

Publisher InTech

Published online 25, November, 2011

Published in print edition November, 2011

This book is a compilation of reviews about the complication of Type 1 Diabetes. T1D is a classic autoimmune disease. Genetic factors are clearly determinant but cannot explain the rapid, even overwhelming expanse of this disease. Understanding etiology and pathogenesis of this disease is essential. The complications associated with T1D cover a range of clinical obstacles. A number of experts in the field have covered a range of topics for consideration that are applicable to researcher and clinician alike. This book provides apt descriptions of cutting edge technologies and applications in the ever going search for treatments and cure for diabetes.

\title{
How to reference
}

In order to correctly reference this scholarly work, feel free to copy and paste the following:

Enrica Favaro, Ilaria Miceli, Elisa Camussi and Maria M. Zanone (2011). Islet Endothelium: Role in Type 1 Diabetes and in Coxsackievirus Infections, Type 1 Diabetes Complications, Prof. David Wagner (Ed.), ISBN: 978-953-307-788-8, InTech, Available from: http://www.intechopen.com/books/type-1-diabetescomplications/islet-endothelium-role-in-type-1-diabetes-and-in-coxsackievirus-infections

\section{INTECH}

open science | open minds

\section{InTech Europe}

University Campus STeP Ri

Slavka Krautzeka 83/A

51000 Rijeka, Croatia

Phone: +385 (51) 770447

Fax: +385 (51) 686166

www.intechopen.com

\section{InTech China}

Unit 405, Office Block, Hotel Equatorial Shanghai

No.65, Yan An Road (West), Shanghai, 200040, China

中国上海市延安西路65号上海国际贵都大饭店办公楼 405 单元

Phone: +86-21-62489820

Fax: $+86-21-62489821$ 
(C) 2011 The Author(s). Licensee IntechOpen. This is an open access article distributed under the terms of the Creative Commons Attribution 3.0 License, which permits unrestricted use, distribution, and reproduction in any medium, provided the original work is properly cited. 